\title{
Predictors of Anxiety in the COVID-19 Pandemic from a Global Perspective: Data from 23 Countries
}

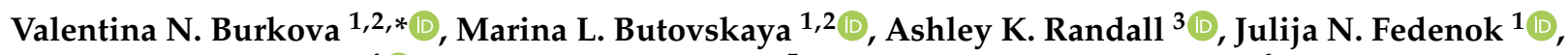 \\ Khodabakhsh Ahmadi ${ }^{4}{ }^{\circ}$, Ahmad M. Alghraibeh ${ }^{5}$, Fathil Bakir Mutsher Allami ${ }^{6}$, Fadime Suata Alpaslan ${ }^{7}$, \\ Mohammad Ahmad Abdelaziz Al-Zu'bi ${ }^{8}$ (D) , Derya Fatma Biçer ${ }^{9}$ (D) Hakan Cetinkaya ${ }^{10}$, \\ Oana Alexandra David ${ }^{11}$, Silvia Donato ${ }^{12}$, Seda Dural ${ }^{13}$, Paige Erickson ${ }^{14}$, Alexey M. Ermakov ${ }^{15}$, \\ Berna Ertuğrul ${ }^{7}$ (D), Emmanuel Abiodun Fayankinnu ${ }^{16}$, Maryanne L. Fisher ${ }^{17}$, Lauren Hocker ${ }^{3}$, Ivana Hromatko ${ }^{18}$, \\ Elena Kasparova ${ }^{19}$, Alexander Kavina ${ }^{20}$, Yahya M. Khatatbeh ${ }^{21}$, Hareesol Khun-Inkeeree ${ }^{22}$, Kai M. Kline ${ }^{3}$, \\ Firat Koç ${ }^{23}$ D , Vladimir Kolodkin 24 (D), Melanie MacEacheron ${ }^{25}$ (D), Irma Rachmawati Maruf ${ }^{26}$, Norbert Meskó ${ }^{27}$, \\ Ruzan Mkrtchyan ${ }^{28}$, Poppy Setiawati Nurisnaeny ${ }^{29}$, Oluyinka Ojedokun ${ }^{30}$ (D), Damilola Adebayo ${ }^{30}$, \\ Mohd S. B. Omar-Fauzee ${ }^{31}$, Barış Özener ${ }^{7}$ (D), Edna Lúcia Tinoco Ponciano ${ }^{32,33}$, Muhammad Rizwan ${ }^{34}$, \\ Agnieszka Sabiniewicz ${ }^{35}$, Victoriya I. Spodina ${ }^{36}$, Stanislava Stoyanova ${ }^{37}$ (D), Nachiketa Tripathi ${ }^{38}$ (D), \\ Satwik Upadhyay ${ }^{38}$, Carol Weisfeld ${ }^{14}$, Mohd Faiz Mohd Yaakob ${ }^{39}$, Mat Rahimi Yusof ${ }^{39}$ and \\ Raushaniia I. Zinurova 40
}

check for updates

Citation: Burkova, V.N.; Butovskaya M.L.; Randall, A.K.; Fedenok, J.N.;

Ahmadi, K.; Alghraibeh, A.M.;

Allami, F.B.M.; Alpaslan, F.S.;

Al-Zu'bi, M.A.A.; Biçer, D.F.; et al.

Predictors of Anxiety in the

COVID-19 Pandemic from a Global

Perspective: Data from 23 Countries.

Sustainability 2021, 13, 4017. https://

doi.org/10.3390/su13074017

Academic Editor: John Rennie Short

Received: 15 February 2021

Accepted: 30 March 2021

Published: 4 April 2021

Publisher's Note: MDPI stays neutral with regard to jurisdictional claims in published maps and institutional affiliations.

Copyright: (c) 2021 by the authors. Licensee MDPI, Basel, Switzerland. This article is an open access article distributed under the terms and conditions of the Creative Commons Attribution (CC BY) license (https:// creativecommons.org/licenses/by/ $4.0 /)$.
1 Center of Cross-Cultural Psychology and Human Ethology, Institute of Ethnology and Anthropology, Russian Academy of Sciences, 119991 Moscow, Russia; marina.butovskaya@gmail.com (M.L.B.); fedenok.julia@gmail.com (J.N.F.)

2 International Center of Anthropology, National Research University Higher School of Economics, 101000 Moscow, Russia

3 Counseling and Counseling Psychology, Arizona State University, Tempe, AZ 85281, USA; Ashley.K.Randall@asu.edu (A.K.R.); lmhocker@asu.edu (L.H.); kkline5@asu.edu (K.M.K.)

4 Behavioral Sciences Research Center, Baqiyatallah University of Medical Sciences, Tehran 19395-5478, Iran; kh_ahmady@yahoo.com

5 Department of Psychology, King Saud University, Riyadh 2458, Saudi Arabia; gha2hmad@yahoo.com

6 Physical Education and Sport Sciences, University of Misan, Amarah, Maysan 62001, Iraq; allamifathil@gmail.com

7 Department of Anthropology, İstanbul University, İstanbul 34452, Turkey; fsuataalpaslan@gmail.com (F.S.A.); bernaozener@yahoo.com.tr (B.E.); barisozener@gmail.com (B.Ö)

8 Department of Early Childhood, Faculty of Educational Sciences, Zarqa University, Zarqa City 5468, Jordan; malzubi@zu.edu.jo

9 Department of Business Administration, Sivas Cumhuriyet University, Sivas 58140, Turkey; dfbicer@cumhuriyet.edu.tr

10 Department of Psychology, Ankara University, Ankara 06100, Turkey; hakan.cetinkaya@ankara.edu.tr

11 Department of Clinical Psychology and Psychotherapy, Babes-Bolyai University Cluj-Napoca,

Cluj-Napoca 400015, Romania; oanadavid@psychology.ro

12 Department of Psychology, Università Cattolica del Sacro Cuore, Milan 20123, Italy; silvia.donato@unicatt.it

13 Department of Psychology, Izmir University of Economics, İzmir 35330, Turkey; seda.dural@ieu.edu.tr

14 Department of Psychology, University of Detroit Mercy, Detroit, MI 48221-3038, USA; erickspa@udmercy.edu (P.E.); weisfecc@udmercy.edu (C.W.)

15 Faculty of Bioengineering and Veterinary Medicine, Don State Technical University, 344000 Rostov-on-Don, Russia; amermakov@ya.ru

16 Department of Sociology, Adekunle Ajasin University, Akungba Akoko 001, Nigeria; emmanuel.fayankinnu@aaua.edu.ng

17 Department of Psychology, Saint Mary's University, Halifax, NS B3H 3C3, Canada; mlfisher.99@gmail.com

18 Department of Psychology, Faculty of Humanities and Social Sciences, 10000 Zagreb, Croatia; ivana.hromatko@ffzg.hr

19 Department of Pedagogy and Problems of Education Development, Belarusian State University, 220030 Minsk, Belarus; elena_arts@mail.ru

20 Department of History, St John's University of Tanzania, Dodoma 47, Tanzania; akavina@sjut.ac.tz

21 Department of Psychology, Imam Muhammad Bin Saud Islamic University, Riyadh 5701, Saudi Arabia; ghahmad@yahoo.com

22 School of Languages and General Education, Walailak University, Thasala District, Nakhon si Thammarat 80160, Thailand; sol.khun75@gmail.com

23 Department of Anthropology, Hitit University, Çorum 19030, Turkey; kocfiratkoc@gmail.com 
24 Faculty of Media Communications and Multimediatechnology, Don State Technical University, 344000 Rostov-on-Don, Russia; vkolodkin@donstu.ru

25 School of Social \& Behavioral Sciences, Arizona State University, Tempe, AZ 85281, USA; mmaceacheron@gmail.com

26 Post Graduate Notary Law Program, Pasundan University, Bandung West Java 40113, Indonesia; irma.rachmawati@unpas.ac.id

27 Department for General and Evolutionary Psychology, Institute of Psychology, University of Pécs, 7624 Pécs, Hungary; mesko.norbert@pte.hu

28 Faculty of History, Department of Cultural Studies, Yerevan State University, 0025 Yerevan, Armenia; ruzantrop55@mail.ru

29 State Intelligence College, Bogor 16001, Indonesia; poppysetiawati@gmail.com

30 Department of Pure \& Applied Psychology, Adekunle Ajasin University, Akungba-Akoko 01, Nigeria; oluyinka.ojedokun@aaua.edu.ng (O.O.); damilola.owolabi@aaua.edu.ng (D.A.)

31 School of Education, Universiti Utara Malaysia, UUM Sintok, Kedah 06010, Malaysia; dromarfauzee@yahoo.com

32 Institute of Psychology and Center of Social Studies, University of the State of Rio de Janeiro, Rio de Janeiro 20943-000, Brazil; ednaponciano@uol.com.br

33 Institute of Psychology and Center of Social Studies, University of Coimbra, 3004 Coimbra, Portugal

34 Department of Psychology, University of Haripur, Khyber Pakhtunkhwa 22620, Pakistan; muhammad29psy@yahoo.com

35 Department of Otorhinolaryngology, Smell and Taste Clinic TU Dresden, 01069 Dresden, Germany; a.sabiniewicz@gmail.com

36 Department of History and Ethnology, Ob-Ugric Institute of Applied Researches and Development, 628011 Khanty-Mansiysk, Russia; vspodina@mail.ru

37 Department of Psychology, South-West University “Neofit Rilski”, 2700 Blagoevgrad, Bulgaria; avka@abv.bg

38 Department of Humanities \& Social Sciences, Indian Institute of Technology Guwahati, Guwahati, Assam 781 039, India; nachi@iitg.ac.in (N.T.); satwi176141011@iitg.ac.in (S.U.)

39 School of Education and Modern Languages, University Utara Malaysia, Sintok, Kedah 06010, Malaysia; mohd.faiz@uum.edu.my (M.F.M.Y.); rahimi@gurumalaysia.edu.my (M.R.Y.)

40 Institute of Innovation Management, Kazan National Research Technological University, 420015 Kazan, Russia; rushazi@rambler.ru

* Correspondence: burkovav@gmail.com

Abstract: Prior and ongoing COVID-19 pandemic restrictions have resulted in substantial changes to everyday life. The pandemic and measures of its control affect mental health negatively. Self-reported data from 15,375 participants from 23 countries were collected from May to August 2020 during the early phases of the COVID-19 pandemic. Two questionnaires measuring anxiety level were used in this study - the Generalized Anxiety Disorder Scale (GAD-7), and the State Anxiety Inventory (SAI). The associations between a set of social indicators on anxiety during COVID-19 (e.g., sex, age, country, live alone) were tested as well. Self-reported anxiety during the first wave of the COVID-19 pandemic varied across countries, with the maximum levels reported for Brazil, Canada, Italy, Iraq and the USA. Sex differences of anxiety levels during COVID-19 were also examined, and results showed women reported higher levels of anxiety compared to men. Overall, our results demonstrated that the self-reported symptoms of anxiety were higher compared to those reported in general before pandemic. We conclude that such cultural dimensions as individualism/collectivism, power distance and looseness/tightness may function as protective adaptive mechanisms against the development of anxiety disorders in a pandemic situation.

Keywords: COVID-19 pandemic; SARS-CoV-2 infection; anxiety; stress; cross-cultural; individualism; collectivism; power distance; looseness; tightness

\section{Introduction}

COVID-19 (SARS-CoV-2) was officially declared a global pandemic on 11 March 2020 by the World Health Organization [1]. Following this declaration, countries around the world started to implement public policy to reduce the spread of the virus, such as implementing social distance guidelines and restricting large gatherings. During the first 
wave of the COVID-19 outbreak, countries introduced various restrictions. Some countries instituted lockdowns and banned all nonessential travel (for example, regions of Canada, Iran, Italy, some states of the USA); others announced partial quarantine and restrictions of varying degrees (Russia, Brazil, Turkey), and some countries limited themselves to advisory measures (Belarus).

COVID-19's impacts can be observed at both the individual and community level. Prior and ongoing COVID-19 restrictions are taking a toll on people's modern lifestyle. Recently published data from 2020 based on sample of adult from different countries revealed that social isolation, and resulting loneliness, are associated with both poorer mental and physical health $[2,3]$. There is evidence that the pandemic, and measures to control it, have negative associations with mental health and important psychosocial and economic consequences [2,4-7] that are affecting children and adults [8-11]. Regarding the contribution of age to stress levels, the data generally indicate that older people are less stressed and less affected by the psychological effects of isolation, whereas being younger predicted higher distress scores [2-4]. Additionally, a review of studies across 10 countries that experienced SARS, Ebola, the H1N1 influenza pandemic, MERS and equine influenza, reported negative psychological effects of quarantine and demonstrated that the psychological impact of quarantine is wide-ranging, substantial, and can be long-lasting [2]. Indeed, prior research on the impact of epidemics, such as SARS, MERS and Ebola, have demonstrated a significant association with symptoms of anxiety due to health threats and people's desire to protect themselves and their loved ones against contagion [2,12-17].

Furthermore, the likelihood of contracting COVID-19 can increase anxiety [18]. Considering that the COVID-19 pandemic has been ongoing, it is obvious that we are facing consequences such as long-term stress, threats to the immune system and increasing susceptibility to viral infections [19]. The increase in anxiety has resulted in an increase of both physical and psychological symptoms, such as feeling nervous, fearful, tense palpitations, hyperventilation and rapid breathing [20,21]. Outside of a global pandemic, women tend to report greater anxiety and stress compared to men [2,22-25], and recent studies on stress levels during a pandemic indicate the same trend $[3,7,26,27]$.

Beyond the individual level, there are community-level factors to consider when examining the associations between COVID-19 and associated outcomes, such as presence (or absence) of other people during the pandemic, intimate relationships and number of children. Participants who rated high in loneliness showed high rates of hostility, depression, insomnia and anxiety before COVID-19 [3,28-30]. For example, a meta-analysis on the harmful effect of loneliness before the pandemic concluded that loneliness is a risk factor for all-cause mortality [31]. However, high-density environments, such as crowding in residential and laboratory settings and household crowding, can also be stressful $[32,33]$, results similar to those in a recent examination on spatial activity in the COVID-19 pandemic [16]. Recent research by Kowal and colleagues (2020) suggested that the association between stress and whom people are living with during isolation is somewhat U-shaped, meaning those who live alone, and those who are overcrowded, experience the highest levels of stress [3].

Culture (e.g., social norms and moral institutions, social distancing rules and social network structure) may be an important factor affecting stress levels during the pandemic. Members of the same culture are socialized to use their culturally specific values to guide their daily survival processes, and there are significant cross-cultural differences in how people assess stressors, choose coping strategies and indicators of adaptive outcomes. Recent research has been published on the effects of COVID-19 on well-being, broadly defined, using cross-cultural samples. For instance, Limcaoco and colleagues (2020) gathered data across 41 countries from 17 March to 1 April 2020, wherein it was demonstrated that the level of anxiety increased [26]. However, a notable limitation of this study was the lack of examination between and within country differences. In another paper, Kowal and colleagues (2020) collected data from 26 countries to examine associations between COVID-19 and stress. Results from this study showed higher levels of stress were associated with 
younger age, being a single woman, lower level of education, staying with more children, and living in a country that has been severely impacted by COVID-19 [3]. In particular, those from Croatia, Japan, Poland and Turkey reported the highest levels of perceived stress. However, further details on cultural differences were not reported. Lastly, Mækelæ and colleagues (2020) assessed how effective a range of restrictions were perceived, how severely they affected daily life, general distress and paranoia during the early phase of the outbreak in Brazil, Colombia, Germany, Israel, Norway and the USA [4]. These authors found a large effect of the country of residency on perceived efficacy of specific restrictions, and that participants from Brazil, Colombia and the USA reported the highest level of distress, whereas people from Israel, Norway and Germany had comparatively lower levels of distress [4]. Again, this study did not explicitly focus on cultural differences, which leaves a dearth of understanding in how culture influences perceptions of the pandemic. Culture is a useful aspect to understand the variations of coping strategies and their effects [34,35].

Many of these studies have raised questions about the impact of cultural dimensions on the course of a pandemic. One of the main focuses of research in this area is the individualism-collectivism dimension [36,37]. Collectivistic vs. individualistic societies put more emphasis on group interest over personal interests and enjoyment [38]. People from collective cultures focus on caring for others, alleviating the negative psychological effects of restrictions and lockdown. Stress levels are expected to be higher for individualistic versus collectivist cultures [3].

The dimension of cultural tightness-looseness refers to the strength of cultural norms [39]. A tight culture (e.g., Pakistan, Singapore, South Korea and China) allows little room for individual liberty and poses high censuring pressure, whereas a loose culture provides members more room for discretion [39]. In tight societies, state authorities tend to make strict behavioral guidance for the public (e.g., social distancing, wearing masks, tracking individual health conditions) and closely monitor and punish deviance [40].

These two constructions (collectivism-individualism and tightness-looseness) are related but clearly differentiated constructs, although collectivism and tightness covary moderately $[38,39,41]$. In the study of Kowal and colleagues (2020) there was no differences in perceived stress levels between countries with varying levels of individualism, but it stated "that people from collectivistic cultures may feel more stressed over their financial burdens than people from individualistic cultures, whereas people from individualistic cultures may treat the current situation as a threat to their need for self-expression and freedom" [3]. Cao and colleagues (2020) showed that neither the Individualism Scale nor the Tightness Index is sufficient to account for differences between countries in COVID-19 containment results [42].

In the process of evolution, humankind has been exposed to various environmental stressors and high pathogen pressure, and pandemics were among them. The ongoing COVID-19 pandemic poses a real threat to humans and demonstrates the current relevance of cultural factors. The fear of any natural threats, according to evolutionary behavioral sciences, is an adaptive defense mechanism, which is necessary for survival [43-45]. Experience from previous epidemics shows that the severity of stress depends on the duration and degree of quarantine, feelings of loneliness, fear of infection, (in)adequate information and stigma $[2,45,46]$. Hence, it is highly probable that anxiety responses to the threat of COVID-19 may change what has been considered normal for everyday functioning, but individuals will likely vary in their reported responses. It is highly probable to observe some visible changes in human behavior as a consequence of the current pandemic [47].

The goal of the present study was to examine possible factors that may be associated with self-reported levels of anxiety during the first wave of the COVID-19 pandemic (from May to August 2020). We hypothesized that spread of the pandemic, isolation measures, and restrictions would result in increased depression symptoms and would worsen the psychological well-being of people world-wide during COVID-19 first wave lockdown. We also hypothesized that cultural dimensions, such as individualism/collectivism, power 
distance, tightness/looseness, and previous familiarity with infections would affect the level of anxiety in society.

\section{Methodology of the Study}

\subsection{Ethics Statement}

The study was conducted according to the principles expressed in the Declaration of Helsinki. The Scientific Council of the Institute of Ethnology and Anthropology of the Russian Academy of Sciences (protocol No 01, dated 9 April 2020) approved the protocols used to recruit participants and to collect data before conducting this study. All participants provided informed consent via a Google form before completing the survey.

\subsection{Participants}

Self-reported data from 15,375 participants were collected from May to August 2020 (see Table 1 for details of sample). The sample comprised of people from 23 countries (seven from Europe: Belarus, Bulgaria, Croatia, Hungary, Italy, Romania, Russia; 11 from West, South and Southeast Asian: Armenia, India, Indonesia, Iran, Iraq, Jordan, Malaysia, Pakistan, Saudi Arabia, Thailand, Turkey; two African: Nigeria and Tanzania; and three from North, South, and Central America: Brazil, Canada, USA).

The mean age of total sample was 29 years old and mean scores of ages in each country are described in Table 1 . The minimal age of respondents was 18-years-old, and the maximum, 89 years old.

Table 1. Distribution of sample by country, $\operatorname{sex}^{1}$ and age.

\begin{tabular}{|c|c|c|c|c|c|}
\hline \multirow{2}{*}{ COUNTRY } & \multirow[t]{2}{*}{ Survey Language } & \multirow[t]{2}{*}{ Total $\mathbf{N}$} & \multicolumn{2}{|c|}{ SEX } & \multirow{2}{*}{$\begin{array}{c}\text { Mean Age } \\
( \pm \text { SD })\end{array}$} \\
\hline & & & Men & Women & \\
\hline ARMENIA & Armenian & 33 & 27 & 6 & $20.45( \pm 2.37)$ \\
\hline BELARUS & Russian & 338 & 143 & 195 & $19.20( \pm 2.85)$ \\
\hline BRAZIL & Portuguese & 515 & 82 & 430 & $38.80( \pm 13.78)$ \\
\hline BULGARIA & Bulgarian & 322 & 129 & 193 & $28.34( \pm 8.75)$ \\
\hline CANADA & English & 692 & 446 & 246 & $30.33( \pm 8.74)$ \\
\hline CROATIA & English & 275 & 71 & 204 & $24.10( \pm 8.40)$ \\
\hline HUNGARY & Hungarian & 235 & 35 & 198 & $31.95( \pm 11.84)$ \\
\hline INDIA & English & 383 & 213 & 170 & $29.95( \pm 9.85)$ \\
\hline INDONESIA & Indonesian & 930 & 504 & 424 & $32.05( \pm 12.09)$ \\
\hline IRAN & Persian & 306 & 88 & 217 & $33.68( \pm 7.34)$ \\
\hline IRAQ & Arabic & 173 & 88 & 85 & $35.03( \pm 10.63)$ \\
\hline ITALY & Italian & 253 & 44 & 208 & $23.50( \pm 4.15)$ \\
\hline JORDAN & Arabic & 449 & 121 & 328 & $33.68( \pm 10.52)$ \\
\hline MALAYSIA & Malay & 1087 & 478 & 609 & $33.19( \pm 11.12)$ \\
\hline NIGERIA & English & 316 & 214 & 102 & $34.09( \pm 11.24)$ \\
\hline PAKISTAN & English & 484 & 212 & 272 & $27.06( \pm 11.11)$ \\
\hline ROMANIA & Romanian & 269 & 42 & 226 & $36.22( \pm 10.94)$ \\
\hline RUSSIA & Russian & 1903 & 486 & 1417 & $20.99( \pm 4.72)$ \\
\hline SAUDI ARABIA & Arabic & 414 & 98 & 316 & $26.76( \pm 9.72)$ \\
\hline TANZANIA & English & 341 & 185 & 156 & $23.95( \pm 4.25)$ \\
\hline TURKEY & Turkish & 4717 & 1609 & 3093 & $27.57( \pm 10.84)$ \\
\hline THAILAND & Thai & 300 & 49 & 250 & $32.82( \pm 13.00)$ \\
\hline USA & English & 666 & 189 & 477 & $45.16( \pm 17.15)$ \\
\hline TOTAL & & 15,375 & 5553 & 9822 & $29.15( \pm 11.80)$ \\
\hline
\end{tabular}

${ }^{1}$ Data on biological sex (not their gender identity) of respondents are presented.

\subsection{Procedure}

All coauthors collected data in their home countries for this study. The questionnaire was generated on the Google Forms service hosted by the principal investigator. The original questionnaire was developed in Russian and English. In all nonEnglish speaking 
countries (except Russia), colleagues translated the measures into their native languages using a back-translation procedure [48,49].

Participants in each country were recruited from various university listservs and social networking sites. We had one exclusion criteria-participants who responded yes to having a chronic disease and/or predisposition for depression and received treatment were excluded. All participants provided informed consent. If eligible, participants were directed to complete the self-report survey on Google forms to provide informed consent, and were asked to take a survey, described below, which took approximately $20 \mathrm{~min}$ to complete. Participants were not compensated for their participation.

The survey was conducted during the first wave of COVID-19 from May to August 2020 (Median 5 June 2020) (see Table 2). We measured the degree of restrictions by asking participants the following yes/no question: Is a self-isolation (quarantine) regime introduced in your country? (yes, no).

Table 2. Dates of Data Collection.

\begin{tabular}{|c|c|c|c|}
\hline COUNTRY & Start Date & End Date & Median \\
\hline ARMENIA & 8 June 2020 & 21 June 2020 & 11 June 2020 \\
\hline BELARUS & 29 April 2020 & 21 June 2020 & 7 May 2020 \\
\hline BRAZIL & 15 May 2020 & 27 July 2020 & 10 June 2020 \\
\hline BULGARIA & 18 May 2020 & 30 June 2020 & 23 June 2020 \\
\hline CANADA & 13 May 2020 & 24 May 2020 & 16 May 2020 \\
\hline CROATIA & 18 May 2020 & 27 August 2020 & 17 July 2020 \\
\hline HUNGARY & 30 June 2020 & 08 August 2020 & 22 May 2020 \\
\hline INDIA & 16 May 2020 & 31 August 2020 & 16 May 2020 \\
\hline INDONESIA & 3 June 2020 & 14 August 2020 & 23 June 2020 \\
\hline IRAN & 21 May 2020 & 17 July 2020 & 28 May 2020 \\
\hline IRAQ & 7 June 2020 & 14 July 2020 & 8 June 2020 \\
\hline ITALY & 4 June 2020 & 29 November 2020 & 12 June 2020 \\
\hline JORDAN & 1 June 2020 & 13 June 2020 & 1 June 2020 \\
\hline MALAYSIA & 12 May 2020 & 22 July 2020 & 10 June 2020 \\
\hline NIGERIA & 4 May 2020 & 9 August 2020 & 31 May 2020 \\
\hline PAKISTAN & 13 May 2020 & 3 August 2020 & 21 May 2020 \\
\hline ROMANIA & 18 May 2020 & 31 August 2020 & 5 June 2020 \\
\hline RUSSIA & 2 May 2020 & 8 August 2020 & 5 May 2020 \\
\hline SAUDI ARABIA & 22 May 2020 & 20 June 2020 & 30 May 2020 \\
\hline TANZANIA & 1 May 2020 & 1 July 2020 & 26 June 2020 \\
\hline TURKEY & 23 May 2020 & 16.07 .2020 & 6 June 2020 \\
\hline THAILAND & 12 May 2020 & 30 May 2020 & 14 May2020 \\
\hline USA & 19 May 2020 & 30 August 2020 & 10 June 2020 \\
\hline TOTAL & & & 5 June 2020 \\
\hline
\end{tabular}

\subsection{Instruments}

Participants completed a standard demographic survey along with the measures listed below. We also asked the following question "Do you live alone or with somebody?" with answers $0=$ no, with somebody, $1=$ yes, alone.

\subsubsection{Measure of Anxiety}

Two questionnaires for measurement of anxiety level were used in this study, the Generalized Anxiety Disorder Scale (GAD-7) [50] and the first part of The State-Trait Anxiety Inventory (STAI) — State Anxiety Inventory (SAI) [51]. We chose two scales of anxiety, as each targets different aspects of this phenomenon. GAD-7 screens for the presence of anxiety and related disorders, while SAI evaluates anxiety as a reaction to stress 
(in our case reaction to COVID-19). Validated measures of the GAD-7 and SAI were used when available [50-61].

\section{Generalized Anxiety Disorder Scale (GAD-7)}

Level of anxiety was measured using the seven-item Generalized Anxiety Disorder Scale (GAD-7) [50], a widely used instrument to screen for the presence of anxiety and related disorders [62]. The GAD-7 consists of seven items and asks participants to rate their symptoms of anxiety using a four-point Likert scale (0 (not at all) to 3 (almost every day) over the past two weeks). Total scores across the seven items were calculated, and anxiety symptoms classified as norm (0-4), mild (5-9), moderate (10-14) and severe (15-21) [50]. The alpha reliability coefficient in the present study for GAD-7 was 0.90 .

State Trait Anxiety Inventory (STAI)

Anxiety as an emotional state was measured using the first part of questionnaire The State-Trait Anxiety Inventory (STAI)—State Anxiety Inventory (SAI) [51]. It was developed to provide reliable, relatively brief self-report scales for assessing state and trait anxiety in research and clinical practice [51]. SAI consists of a 20-item scale for measuring the intensity of anxiety as an emotional state. Participants reported the intensity of their feelings of anxiety in that moment by rating themselves on the following four-point Likert scale from 1 (not at all) to 4 (very much so). Total scores of anxiety symptoms were classified as norm/low (0-30), moderate (31-45) and high (46 and above) [51]. The alpha reliability coefficient in the present study for SAI was 0.77 .

\subsection{Global Indices}

Individualism versus Collectivism. Global indices were examined in this study, as represented by the Hofstede model (the Individualism versus Collectivism scale, related to the integration of individuals into primary groups and the Power Distance scale, related to the different solutions to the basic problem of human inequality) [36]. Each country was positioned relative to other countries through a score on each dimension. Individualism stands for a society in which the ties between individuals are loose and everyone is expected to look after her/his immediate family only. Collectivism stands for a society in which people from birth onwards are integrated into strong, cohesive in-groups, which throughout people's lifetime continue to protect them in exchange for unquestioning loyalty [36] (p. 225). Power Distance has been defined as the extent to which the less powerful members of organizations and institutions (like the family) accept and expect that power is distributed unequally. This represents inequality (more versus less), but defined from below, not from above. It suggests that a society's level of inequality is endorsed by the followers as much as by the leaders [37] (p. 9). Information about this indicator in each country was obtained from https:/ / www.hofstede-insights.com (accessed date 5 June 2020).

Tightness-looseness index. The Tightness-Looseness Index (Tightness score) was assessed if available for our study samples, with data acquired from the paper of Gelfand and coauthors [39]. This score demonstrates the differences between cultures that are tight (i.e., those that have strong norms and a low tolerance of deviant behavior) compared to those that are loose (i.e., those that have weak social norms and a high tolerance of deviant behavior) [39]. Due to the fact that not all the countries were represented in Gelfand's work (i.e., Jordan, Indonesia, Iran, Iraq, Nigeria, Russia, Tanzania), we applied the Index of Cultural Tightness and Looseness (CTL) from the study of Uz as well [63].

Vulnerability to disease. We used the Infectious Disease Vulnerability Index (IDVI) as a country-level index of potential vulnerability to infectious disease outbreaks [64]. IDVI is a country-level index of vulnerability. This index was selected because it represents a robust measure of infectious disease vulnerability in four ways: a more comprehensive evidence base, a more robust set of factors potentially contributing to outbreak vulnerability and associated proxy measures, the use of adjustable weights for these parameters, and an 
examination of all countries world-wide. Information about this indicator in each country was obtained from https://www.rand.org/pubs/research_reports/RR1605.html.

\subsection{Data Analysis}

SPSS (Version 27.0) was employed for data evaluation. Data were evaluated for missingness, but we chose to retain all. An analysis of descriptive statistics was conducted to illustrate the demographic and selected characteristics of the respondents. T tests were conducted to examine potential sex differences in ratings on the GAD-7 and SAI scales. Linear regression was used to test the associations between the GAD-7, SAI scales and global indexes, denoted above. Lastly, a GLM ANOVA was used for analysis of the GAD-7 and SAI to estimate the association between sex and country on levels of anxiety.

\section{Results}

\subsection{Sex and Country Differences of Anxiety Scales}

Mean and standard deviations across countries are represented in Table 3. Countryspecific sex differences revealed significant sex differences of GAD-7 for individuals from Belarus, Bulgaria, Canada, Croatia, India, Indonesia, Italy, Jordan, Malaysia, Nigeria, Pakistan, Romania, Russia, Tanzania, and Turkey. For the SAI, women from Belarus, Brazil, Bulgaria, Canada, Croatia, India, Indonesia, Italy, Jordan, Malaysia, Pakistan, Russia and Turkey reported higher ratings of anxiety across both scales. The Pearson's correlation analysis, controlling for country and sex, revealed a strong positive correlation between the GAD-7 and SAI total scores $(r=0.49, p=0.0001)$.

The results of GLM ANOVAs with GAD-7 as the dependent variable, sex and country as fixed factors and significant main effects of sex $\left(\mathrm{F}_{(1,15340)}=298.885, p<0.001, \eta^{2}=0.019\right)$ and country $\left(\mathrm{F}_{(22,15345)}=53.758, p<0.001, \eta^{2}=0.072\right)$, showed small and medium effect sizes accordingly. In the case of SAI as the dependent variable we found main effects of $\operatorname{sex}\left(\mathrm{F}_{(1,15268)}=157.504, p<0.001, \eta^{2}=0.010\right)$ and country $\left(\mathrm{F}_{(22,15273)}=67.872, p<0.001\right.$, $\left.\eta^{2}=0.089\right)$, both with medium effect sizes.

Table 3. Sex differences in Generalized Anxiety Disorder Scale (GAD-7) and the State Anxiety Inventory (SAI) across countries.

\begin{tabular}{|c|c|c|c|c|c|c|c|c|c|c|}
\hline \multirow{2}{*}{ COUNTRY } & \multirow{2}{*}{ Scales } & \multirow{2}{*}{ Sex } & \multirow{2}{*}{$\mathbf{N}$} & \multirow{2}{*}{ mean $M$} & \multirow{2}{*}{$\mathbf{t}$} & \multirow{2}{*}{ df } & \multirow{2}{*}{$\mathbf{P}$} & \multicolumn{2}{|c|}{$95 \%$ CI } & \multirow{2}{*}{$\begin{array}{c}\text { Effect Size } \\
\text { (Hedges' Correction) * }\end{array}$} \\
\hline & & & & & & & & Lower & Upper & \\
\hline \multirow{2}{*}{ ARMENIA } & GAD-7 & $\begin{array}{c}\text { men } \\
\text { women }\end{array}$ & $\begin{array}{c}27 \\
6\end{array}$ & $\begin{array}{l}5.81 \\
4.00\end{array}$ & 0.808 & 31 & 0.425 & -2.767 & 6.397 & 0.356 \\
\hline & SAI & $\begin{array}{c}\text { men } \\
\text { women }\end{array}$ & $\begin{array}{c}27 \\
6\end{array}$ & $\begin{array}{l}30.93 \\
26.17\end{array}$ & 0.847 & 31 & 0.403 & -6.701 & 16.219 & 0.373 \\
\hline \multirow{2}{*}{ BELARUS } & GAD-7 & $\begin{array}{c}\text { men } \\
\text { women }\end{array}$ & $\begin{array}{l}143 \\
195\end{array}$ & $\begin{array}{l}5.10 \\
6.46\end{array}$ & -2.702 & 336 & 0.007 & -2.344 & -0.369 & -0.297 \\
\hline & SAI & $\begin{array}{c}\text { men } \\
\text { women }\end{array}$ & $\begin{array}{l}143 \\
195\end{array}$ & $\begin{array}{l}29.01 \\
32.43\end{array}$ & -3.055 & 336 & 0.002 & -5.617 & -1.217 & -0.336 \\
\hline \multirow{2}{*}{ BRAZIL } & GAD-7 & $\begin{array}{c}\text { men } \\
\text { women }\end{array}$ & $\begin{array}{c}82 \\
430\end{array}$ & $\begin{array}{l}7.99 \\
8.49\end{array}$ & -0.800 & 126 & 0.425 & -1.738 & 0.737 & -0.087 \\
\hline & SAI & $\begin{array}{c}\text { men } \\
\text { women }\end{array}$ & $\begin{array}{c}82 \\
430\end{array}$ & $\begin{array}{l}36.27 \\
39.94\end{array}$ & -2.513 & 510 & 0.012 & -6.541 & -0.801 & -0.302 \\
\hline \multirow[b]{2}{*}{ BULGARIA } & GAD-7 & $\begin{array}{c}\text { men } \\
\text { women }\end{array}$ & $\begin{array}{l}129 \\
193\end{array}$ & $\begin{array}{l}5.87 \\
7.32\end{array}$ & -2.821 & 308 & 0.005 & -2.467 & -0.440 & -0.307 \\
\hline & SAI & $\begin{array}{c}\text { men } \\
\text { women }\end{array}$ & $\begin{array}{l}129 \\
193\end{array}$ & $\begin{array}{l}26.18 \\
30.48\end{array}$ & -3.325 & 314 & 0.001 & -6.842 & -1.755 & -0.358 \\
\hline \multirow{2}{*}{ CANADA } & GAD-7 & $\begin{array}{c}\text { men } \\
\text { women }\end{array}$ & $\begin{array}{l}420 \\
239\end{array}$ & $\begin{array}{l}7.75 \\
8.71\end{array}$ & -2.209 & 657 & 0.028 & -1.812 & -0.107 & -0.179 \\
\hline & SAI & $\begin{array}{c}\text { men } \\
\text { women }\end{array}$ & $\begin{array}{l}382 \\
227\end{array}$ & $\begin{array}{l}31.03 \\
33.18\end{array}$ & -2.403 & 607 & 0.017 & -3.902 & -0.393 & -0.201 \\
\hline
\end{tabular}


Table 3. Cont.

\begin{tabular}{|c|c|c|c|c|c|c|c|c|c|c|}
\hline \multirow{2}{*}{ COUNTRY } & \multirow{2}{*}{ Scales } & \multirow{2}{*}{ Sex } & \multirow{2}{*}{$\mathbf{N}$} & \multirow{2}{*}{ mean $M$} & \multirow{2}{*}{$\mathbf{t}$} & \multirow{2}{*}{ df } & \multirow{2}{*}{$\mathbf{P}$} & \multicolumn{2}{|c|}{$95 \% \mathrm{CI}$} & \multirow{2}{*}{$\begin{array}{c}\text { Effect Size } \\
\text { (Hedges' Correction) }\end{array}$} \\
\hline & & & & & & & & Lower & Upper & \\
\hline \multirow[b]{2}{*}{ CROATIA } & GAD-7 & $\begin{array}{c}\text { men } \\
\text { women }\end{array}$ & $\begin{array}{c}71 \\
204\end{array}$ & $\begin{array}{l}6.44 \\
7.77\end{array}$ & -2.056 & 273 & 0.041 & -2.610 & -0.056 & -0.282 \\
\hline & SAI & $\begin{array}{c}\text { men } \\
\text { women }\end{array}$ & $\begin{array}{c}71 \\
204\end{array}$ & $\begin{array}{l}24.61 \\
29.61\end{array}$ & -3.049 & 273 & 0.003 & -8.249 & -1.774 & -0.419 \\
\hline \multirow[b]{2}{*}{ HUNGARY } & GAD-7 & $\begin{array}{c}\text { men } \\
\text { women }\end{array}$ & $\begin{array}{c}35 \\
198\end{array}$ & $\begin{array}{l}3.69 \\
5.16\end{array}$ & -1.784 & 231 & 0.076 & -3.096 & 0.154 & -0.326 \\
\hline & SAI & $\begin{array}{c}\text { men } \\
\text { women }\end{array}$ & $\begin{array}{c}35 \\
198\end{array}$ & $\begin{array}{l}24.83 \\
28.73\end{array}$ & -1.750 & 231 & 0.081 & -8.299 & 0.491 & -0.320 \\
\hline \multirow[b]{2}{*}{ INDIA } & GAD-7 & $\begin{array}{c}\text { men } \\
\text { women }\end{array}$ & $\begin{array}{l}213 \\
170\end{array}$ & $\begin{array}{l}5.37 \\
6.79\end{array}$ & -2.822 & 381 & 0.005 & -2.413 & -0.431 & -0.290 \\
\hline & SAI & $\begin{array}{c}\text { men } \\
\text { women }\end{array}$ & $\begin{array}{l}213 \\
170\end{array}$ & $\begin{array}{l}30.23 \\
33.54\end{array}$ & -3.553 & 381 & 0.0004 & -5.151 & -1.481 & -0.365 \\
\hline \multirow[b]{2}{*}{ INDONESIA } & GAD-7 & $\begin{array}{c}\text { men } \\
\text { women }\end{array}$ & $\begin{array}{l}504 \\
424\end{array}$ & $\begin{array}{l}3.27 \\
5.59\end{array}$ & -7.797 & 828 & $<0.001$ & -2.912 & -1.741 & -0.521 \\
\hline & SAI & $\begin{array}{c}\text { men } \\
\text { women }\end{array}$ & $\begin{array}{l}504 \\
424\end{array}$ & $\begin{array}{l}26.48 \\
30.47\end{array}$ & -5.617 & 926 & $<0.001$ & -5.380 & -2.594 & -0.370 \\
\hline \multirow{2}{*}{ IRAN } & GAD-7 & $\begin{array}{c}\text { men } \\
\text { women }\end{array}$ & $\begin{array}{c}88 \\
217\end{array}$ & $\begin{array}{l}5.57 \\
5.77\end{array}$ & -0.373 & 303 & 0.710 & -1.294 & 0.882 & -0.047 \\
\hline & SAI & $\begin{array}{c}\text { men } \\
\text { women }\end{array}$ & $\begin{array}{c}88 \\
217\end{array}$ & $\begin{array}{l}34.75 \\
35.00\end{array}$ & -0.656 & 303 & 0.513 & -1.019 & 0.510 & -0.083 \\
\hline \multirow{2}{*}{ IRAQ } & GAD-7 & $\begin{array}{c}\text { men } \\
\text { women }\end{array}$ & $\begin{array}{l}88 \\
85\end{array}$ & $\begin{array}{l}8.81 \\
9.52\end{array}$ & -0.944 & 171 & 0.347 & -2.197 & 0.776 & -0.143 \\
\hline & SAI & $\begin{array}{c}\text { men } \\
\text { women }\end{array}$ & $\begin{array}{l}88 \\
85\end{array}$ & $\begin{array}{l}31.16 \\
33.74 \\
\end{array}$ & -1.726 & 171 & 0.086 & -5.535 & 0.371 & -0.261 \\
\hline \multirow[b]{2}{*}{ ITALY } & GAD-7 & $\begin{array}{c}\text { men } \\
\text { women }\end{array}$ & $\begin{array}{c}44 \\
208\end{array}$ & $\begin{array}{l}6.09 \\
7.96\end{array}$ & -2.712 & 250 & 0.007 & -3.229 & -0.512 & -0.449 \\
\hline & SAI & $\begin{array}{c}\text { men } \\
\text { women }\end{array}$ & $\begin{array}{c}44 \\
208 \\
\end{array}$ & $\begin{array}{l}35.20 \\
39.05\end{array}$ & -2.152 & 250 & 0.032 & -7.371 & -0.326 & -0.356 \\
\hline \multirow{2}{*}{ JORDAN } & GAD-7 & $\begin{array}{c}\text { men } \\
\text { women }\end{array}$ & $\begin{array}{l}121 \\
328 \\
\end{array}$ & $\begin{array}{l}4.94 \\
7.13\end{array}$ & -4.326 & 447 & $<0.001$ & -3.174 & -1.191 & -0.459 \\
\hline & SAI & $\begin{array}{c}\text { men } \\
\text { women }\end{array}$ & $\begin{array}{l}121 \\
328\end{array}$ & $\begin{array}{l}26.43 \\
29.06\end{array}$ & -2.305 & 447 & 0.022 & -4.875 & -0.388 & -0.245 \\
\hline \multirow[b]{2}{*}{ MALAYSIA } & GAD-7 & $\begin{array}{c}\text { men } \\
\text { women }\end{array}$ & $\begin{array}{l}478 \\
609 \\
\end{array}$ & $\begin{array}{l}2.68 \\
3.54 \\
\end{array}$ & -3.484 & 1072 & 0.001 & -1.337 & -0.374 & -0.329 \\
\hline & SAI & $\begin{array}{c}\text { men } \\
\text { women }\end{array}$ & $\begin{array}{l}477 \\
609\end{array}$ & $\begin{array}{l}28.98 \\
27.57\end{array}$ & 2.267 & 1064 & 0.024 & 0.189 & 2.627 & 0.137 \\
\hline \multirow{2}{*}{ NIGERIA } & GAD-7 & $\begin{array}{c}\text { men } \\
\text { women }\end{array}$ & $\begin{array}{l}214 \\
102\end{array}$ & $\begin{array}{l}3.98 \\
5.26\end{array}$ & -2.003 & 158 & 0.047 & -2.549 & -0.018 & -0.265 \\
\hline & SAI & $\begin{array}{c}\text { men } \\
\text { women }\end{array}$ & $\begin{array}{l}214 \\
102\end{array}$ & $\begin{array}{l}24.77 \\
25.51\end{array}$ & -0.572 & 314 & 0.567 & -3.278 & 1.801 & -0.069 \\
\hline \multirow{2}{*}{ PAKISTAN } & GAD-7 & $\begin{array}{c}\text { men } \\
\text { women }\end{array}$ & $\begin{array}{l}212 \\
272\end{array}$ & $\begin{array}{l}5.20 \\
6.90\end{array}$ & -3.624 & 482 & $<0.001$ & -2.631 & -0.781 & -0.331 \\
\hline & SAI & $\begin{array}{c}\text { men } \\
\text { women }\end{array}$ & $\begin{array}{l}212 \\
272\end{array}$ & $\begin{array}{l}28.20 \\
32.72\end{array}$ & -4.282 & 482 & $<0.001$ & -6.592 & -2.445 & -0.392 \\
\hline \multirow{2}{*}{ ROMANIA } & GAD-7 & $\begin{array}{c}\text { men } \\
\text { women }\end{array}$ & $\begin{array}{c}42 \\
226\end{array}$ & $\begin{array}{l}4.12 \\
5.79\end{array}$ & -2.138 & 266 & 0.033 & -3.205 & -0.132 & -0.358 \\
\hline & SAI & $\begin{array}{c}\text { men } \\
\text { women }\end{array}$ & $\begin{array}{c}42 \\
226\end{array}$ & $\begin{array}{l}21.45 \\
24.19\end{array}$ & -1.395 & 266 & 0.164 & -6.612 & 1.127 & -0.234 \\
\hline \multirow{2}{*}{ RUSSIA } & GAD-7 & $\begin{array}{c}\text { men } \\
\text { women }\end{array}$ & $\begin{array}{c}486 \\
1417\end{array}$ & $\begin{array}{l}3.80 \\
5.71\end{array}$ & -7.951 & 938 & $<0.001$ & -2.381 & -1.438 & -0.394 \\
\hline & SAI & $\begin{array}{c}\text { men } \\
\text { women }\end{array}$ & $\begin{array}{c}486 \\
1417\end{array}$ & $\begin{array}{l}25.34 \\
29.47\end{array}$ & -6.761 & 1901 & $<0.001$ & -5.335 & -2.936 & -0.355 \\
\hline
\end{tabular}


Table 3. Cont.

\begin{tabular}{|c|c|c|c|c|c|c|c|c|c|c|}
\hline \multirow{2}{*}{ COUNTRY } & \multirow{2}{*}{ Scales } & \multirow{2}{*}{ Sex } & \multirow{2}{*}{$\mathbf{N}$} & \multirow{2}{*}{ mean $M$} & \multirow{2}{*}{$\mathbf{t}$} & \multirow{2}{*}{ df } & \multirow{2}{*}{$\mathbf{P}$} & \multicolumn{2}{|c|}{$95 \% \mathrm{CI}$} & \multirow{2}{*}{$\begin{array}{c}\text { Effect Size } \\
\text { (Hedges' Correction) * }\end{array}$} \\
\hline & & & & & & & & Lower & Upper & \\
\hline \multirow{2}{*}{$\begin{array}{c}\text { SAUDI } \\
\text { ARABIA }\end{array}$} & GAD-7 & $\begin{array}{c}\text { men } \\
\text { women }\end{array}$ & $\begin{array}{c}98 \\
316\end{array}$ & $\begin{array}{l}5.40 \\
5.55\end{array}$ & -0.290 & 412 & 0.772 & -1.211 & 0.899 & -0.034 \\
\hline & SAI & $\begin{array}{c}\text { men } \\
\text { women }\end{array}$ & $\begin{array}{c}98 \\
316\end{array}$ & $\begin{array}{l}26.15 \\
27.34\end{array}$ & -0.843 & 412 & 0.400 & -3.949 & 1.578 & -0.097 \\
\hline \multirow[b]{2}{*}{ TANZANIA } & GAD-7 & $\begin{array}{c}\text { men } \\
\text { women }\end{array}$ & $\begin{array}{l}185 \\
156\end{array}$ & $\begin{array}{l}4.39 \\
5.65\end{array}$ & -2.304 & 339 & 0.022 & -2.332 & -0.184 & -0.250 \\
\hline & SAI & $\begin{array}{c}\text { men } \\
\text { women }\end{array}$ & $\begin{array}{l}185 \\
156\end{array}$ & $\begin{array}{l}32.43 \\
33.25\end{array}$ & -1.261 & 339 & 0.208 & -2.107 & 0.461 & -0.137 \\
\hline \multirow[b]{2}{*}{ THAILAND } & GAD-7 & $\begin{array}{c}\text { men } \\
\text { women }\end{array}$ & $\begin{array}{c}49 \\
250\end{array}$ & $\begin{array}{l}3.33 \\
4.20\end{array}$ & -1.679 & 88 & 0.097 & -1.898 & 0.159 & -0.212 \\
\hline & SAI & $\begin{array}{c}\text { men } \\
\text { women }\end{array}$ & $\begin{array}{c}49 \\
250\end{array}$ & $\begin{array}{l}28.59 \\
31.01\end{array}$ & -1.864 & 297 & 0.063 & -4.967 & 0.134 & -0.291 \\
\hline \multirow{2}{*}{ TURKEY } & GAD-7 & $\begin{array}{c}\text { men } \\
\text { women }\end{array}$ & $\begin{array}{l}1609 \\
3093\end{array}$ & $\begin{array}{l}5.76 \\
7.42\end{array}$ & -11.412 & 3473 & $<0.001$ & -1.942 & -1.372 & -0.354 \\
\hline & SAI & $\begin{array}{c}\text { men } \\
\text { women }\end{array}$ & $\begin{array}{l}1609 \\
3093\end{array}$ & $\begin{array}{l}32.14 \\
33.74\end{array}$ & -6.836 & 3718 & $<0.001$ & -2.057 & -1.140 & -0.200 \\
\hline \multirow[b]{2}{*}{ USA } & GAD-7 & $\begin{array}{c}\text { men } \\
\text { women }\end{array}$ & $\begin{array}{l}189 \\
477\end{array}$ & $\begin{array}{l}5.85 \\
6.52\end{array}$ & -1.447 & 664 & 0.148 & -1.587 & 0.241 & -0.124 \\
\hline & SAI & $\begin{array}{c}\text { men } \\
\text { women }\end{array}$ & $\begin{array}{l}184 \\
461\end{array}$ & $\begin{array}{l}25.80 \\
27.72\end{array}$ & -1.620 & 643 & 0.106 & -4.248 & 0.407 & 0.141 \\
\hline \multirow{2}{*}{$\begin{array}{l}\text { TOTAL } \\
\text { SAMPLE }\end{array}$} & GAD-7 & $\begin{array}{c}\text { men } \\
\text { women }\end{array}$ & $\begin{array}{l}5527 \\
9815\end{array}$ & $\begin{array}{l}5.10 \\
6.55\end{array}$ & -17.620 & 12,056 & $<0.001$ & -1.614 & -1.288 & -0.292 \\
\hline & SAI & $\begin{array}{c}\text { men } \\
\text { women }\end{array}$ & $\begin{array}{l}5483 \\
9787\end{array}$ & $\begin{array}{l}29.34 \\
31.65\end{array}$ & -13.133 & 11,997 & $<0.001$ & -2.655 & -1.965 & -0.216 \\
\hline
\end{tabular}

$\mathrm{N}$-number of cases, $\mathrm{t}$ - - test statistics, $\mathrm{df}$ - degrees of freedom, $\mathrm{p}$ - statistical significance, NS-not significant, $\mathrm{CI}$-Confidence Interval of the Difference. * Hedges' $g$, which provides a measure of effect size weighted according to the relative size of each sample, is an alternative where there are different sample sizes.

GAD-7. A total of 7045 participants (45.84\%) across the entire sample reported minimal (norm) symptoms of anxiety; 4830 (31.43\%) reported mild symptoms, 2366 (15.40\%) reported moderate symptoms and 1127 (7.33\%) reported severe symptoms (see Figure 1a).

SAI. A total of 6589 participants $(43.08 \%)$ across the entire sample reported a low level of anxiety, $7560(49.42 \%)$ respondents reported moderate values, and $1147(7.50 \%)$ respondents reported high values (see Figure 1b).
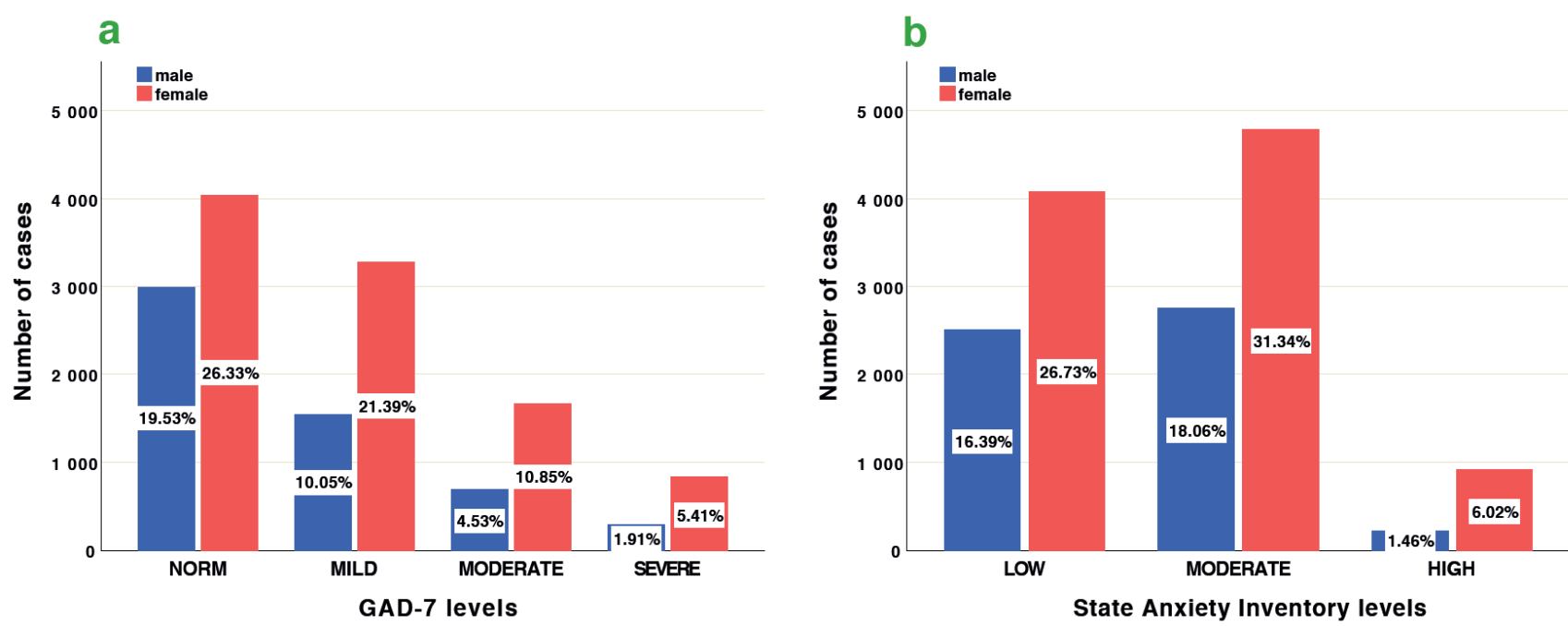

Figure 1. Sex differences of levels on GAD-7 (a) and SAI (b). 
Our data revealed that the most stressed countries during restrictions and lockdown of the first wave of COVID-19 were Brazil, Iraq, Canada and the USA when looking at the GAD-7 scale (see Figure 2a). Most of the highest levels of state anxiety (SAI) were in Brazil and Italy (see Figure 2b).

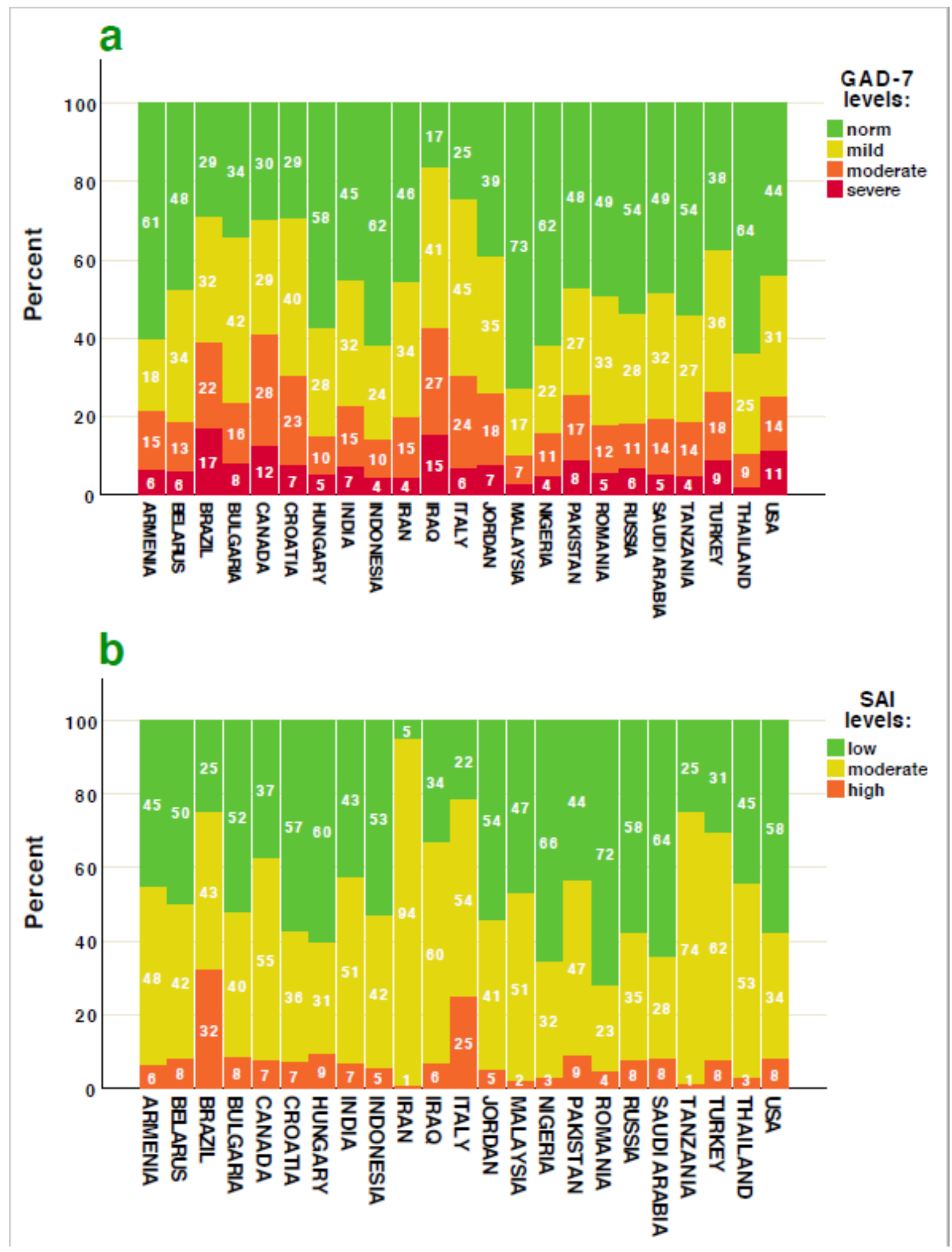

Figure 2. Levels of GAD-7 (a) and SAI (b) across 23 countries during first wave of COVID-19. 


\subsection{Global Indices}

To evaluate the association between global indices and self-reported symptoms of anxiety, we used a regression analysis.

Individualism. The countries with high ratings of anxiety were also rated high on individualism (beta $=0.108, \mathrm{t}=13.510, p<0.001, \mathrm{R}^{2}=0.012$ ). Participants in countries with the lowest level of individualism (Indonesia, Malaysia, Nigeria, and Thailand) also reported the lowest levels of anxiety, except for Iraq (see Figure 3a). Similar trends were observed for the SAI (beta $=0.030, t=3.653, p<0.001, R^{2}=0.001$ ) (see Figure $3 b$ ).
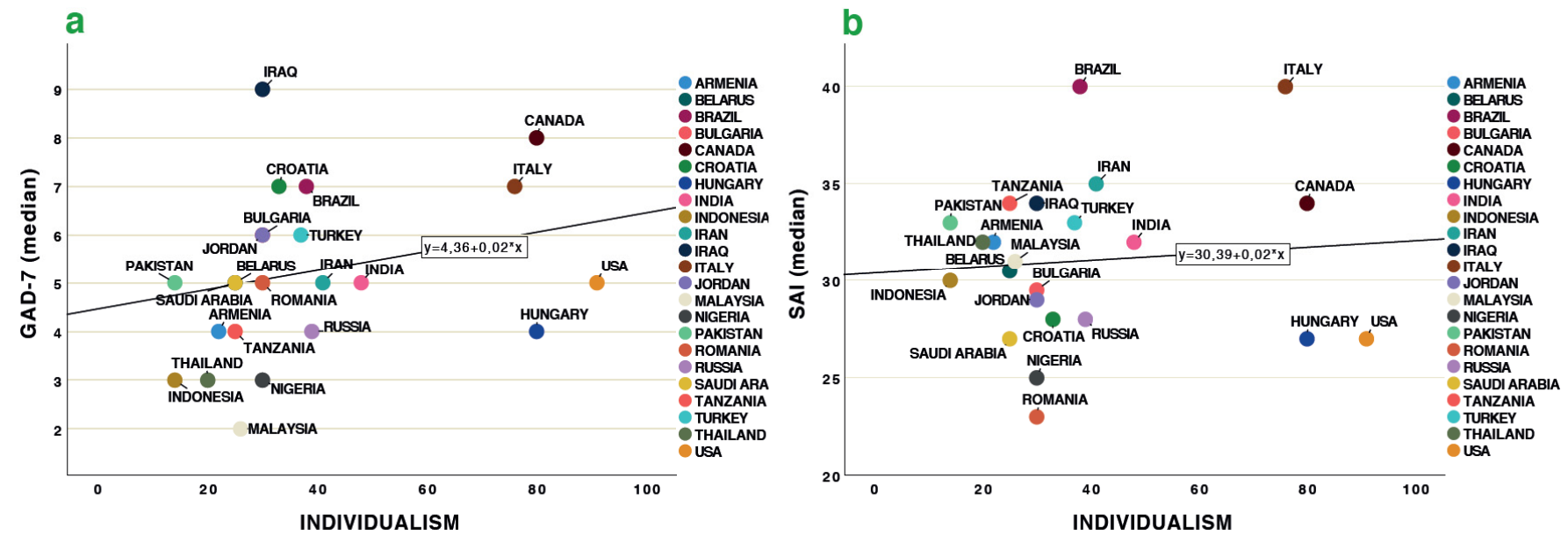

Figure 3. Association between individualism and GAD-7 (a), and SAI (b) across 23 countries.

Power distance. Higher GAD-7 ratings on anxiety were found for nations with low power distance (beta $=-0.046, t=-19.616, p<0.001, \mathrm{R}^{2}=0.024$ ), except for Iraq. See Figure 4a. Similar trends were observed for SAI (beta $=-0.121, \mathrm{t}=-15.090, p<0.001$, $\left.R^{2}=0.015\right)$. See Figure $4 b$.
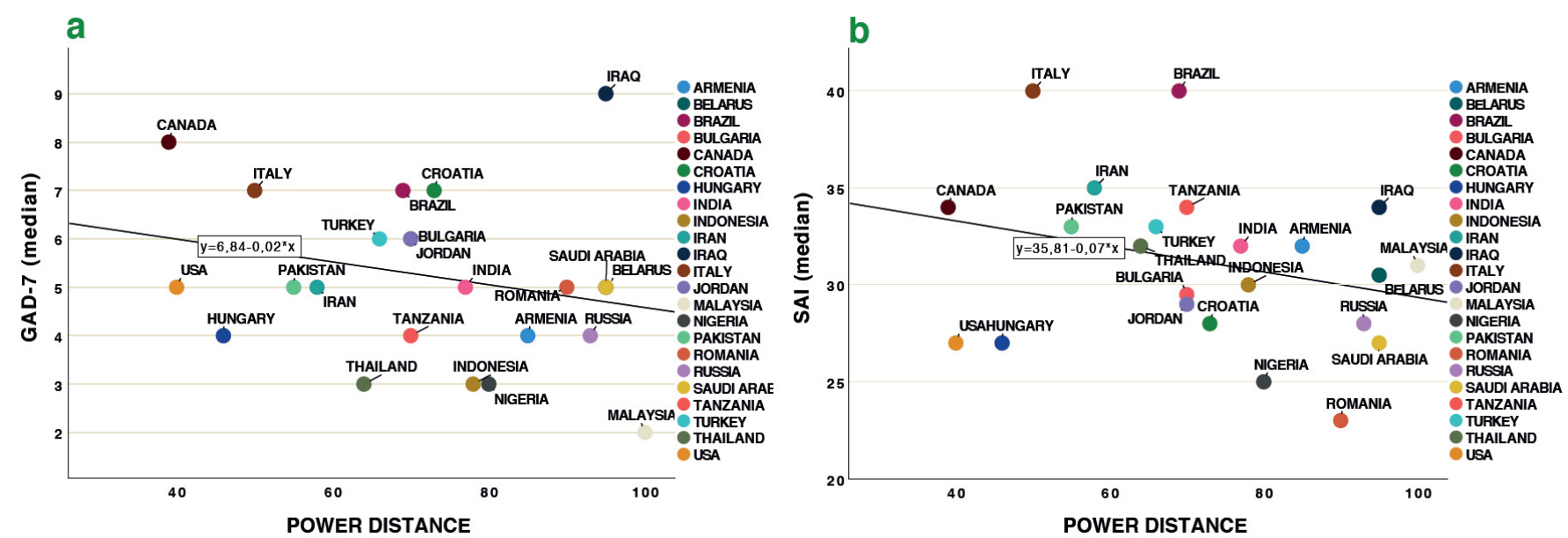

Figure 4. Association between power distance and GAD-7 (a), and SAI (b) across 23 countries.

IDVI. Higher GAD-7 ratings on anxiety were found for nations with low vulnerability (beta $=0.062, t=7.726, p<0.001, R^{2}=0.062$ ), except for Iraq (see Figure 5a). The most vulnerable to infectious diseases, but the least anxious countries were Nigeria, Tanzania, Pakistan (see Figure 5a), with the exception of Iraq. Similar trends were observed for SAI (beta $=0.014, t=1.748, p=0.081, R^{2}=0.000$ ) (Figure 5b). 

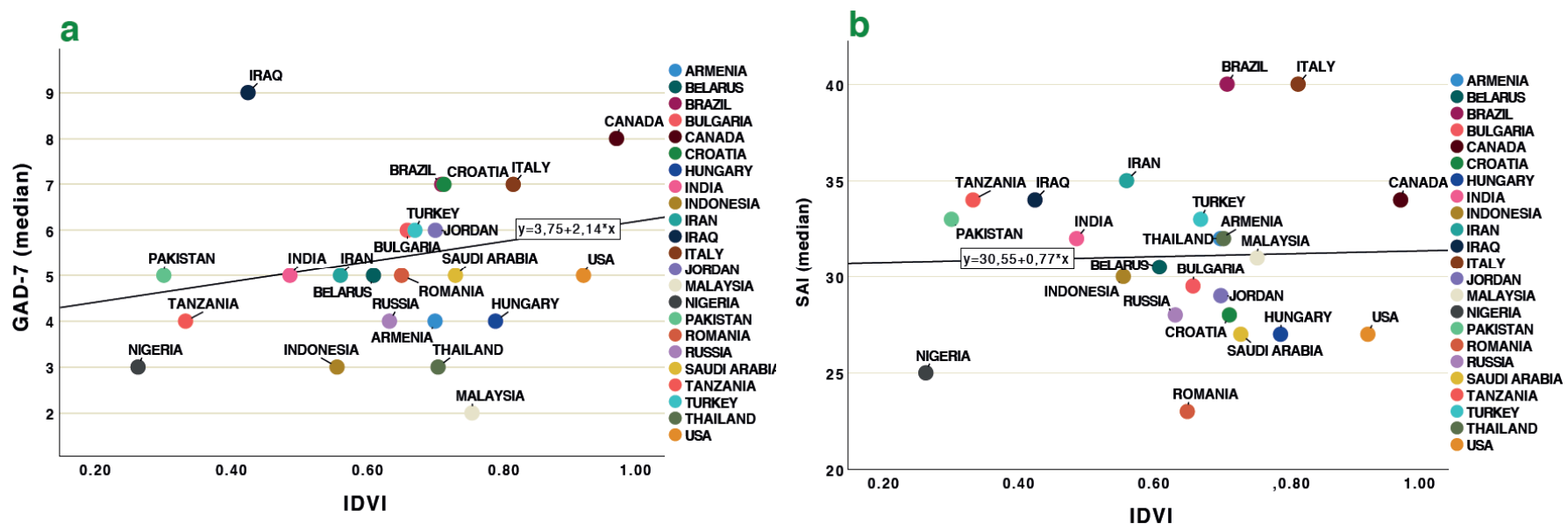

Figure 5. Association between Infectious Disease Vulnerability Index GAD-7 (a), and SAI (b) across 23 countries.

Tightness index. Countries who were high in measures of tightness reported the lowest ratings of anxiety on the GAD-7 (beta $=-0.137, \mathrm{t}=-12.628, p<0.001, \mathrm{R}^{2}=0.019$ ) (see Figure 6a). Similar trends were observed for SAI (beta $=-0.092, \mathrm{t}=-8.417, p<0.001$, $\mathrm{R}^{2}=0.008$ ) (see Figure 6b).
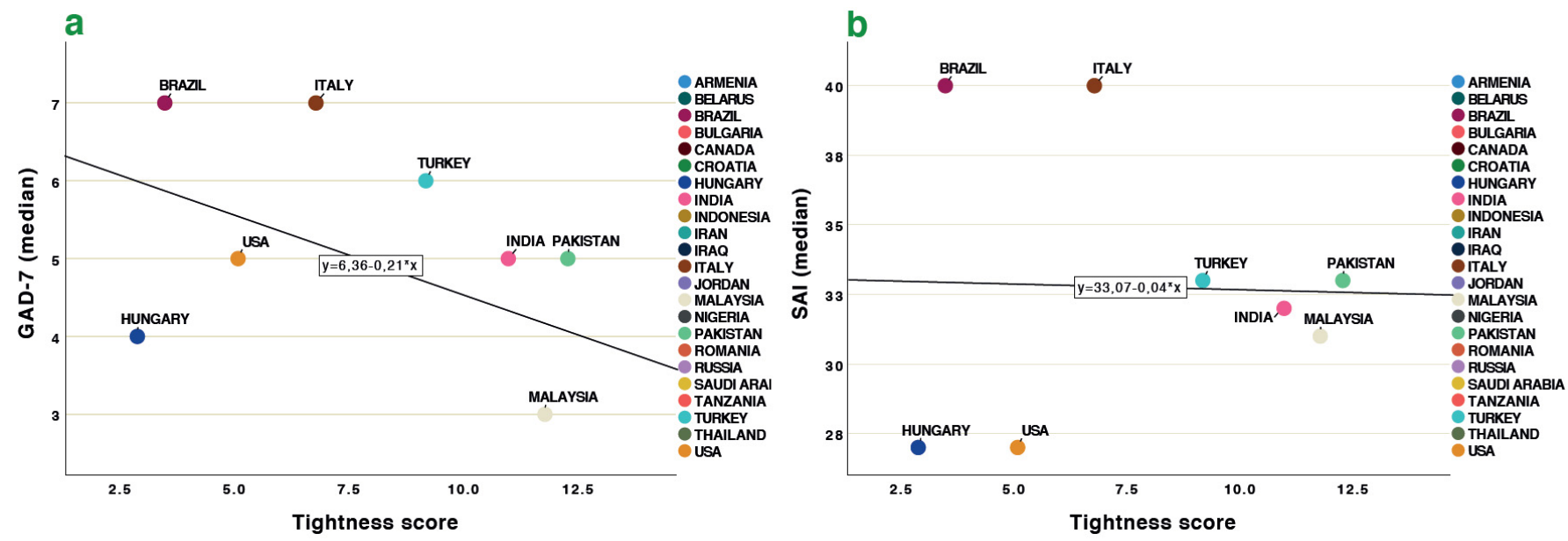

Figure 6. Association between Tightness score and GAD-7 (a), SAI, (b) across 23 countries (Figure 6 shows only those countries for which the Tightness index was available [39]).

Index of Cultural tightness and looseness. Similar tendencies were demonstrated in the case of Index of Cultural Tightness and Looseness (CTL) [63]. Very loose nations (such as Canada and Italy) rated higher on both the GAD-7 (beta $=-0.137, \mathrm{t}=-12.628$, $p<0.001, \mathrm{R}^{2}=0.019$ ) and the SAI (beta $=-0.066, \mathrm{t}=-7.491, p<0.001, \mathrm{R}^{2}=0.004$ ) (see Figure $7 \mathrm{a}, \mathrm{b}$, respectively). On the other side of the pole was Indonesia, Nigeria and Jordan (Figure 7a,b). 

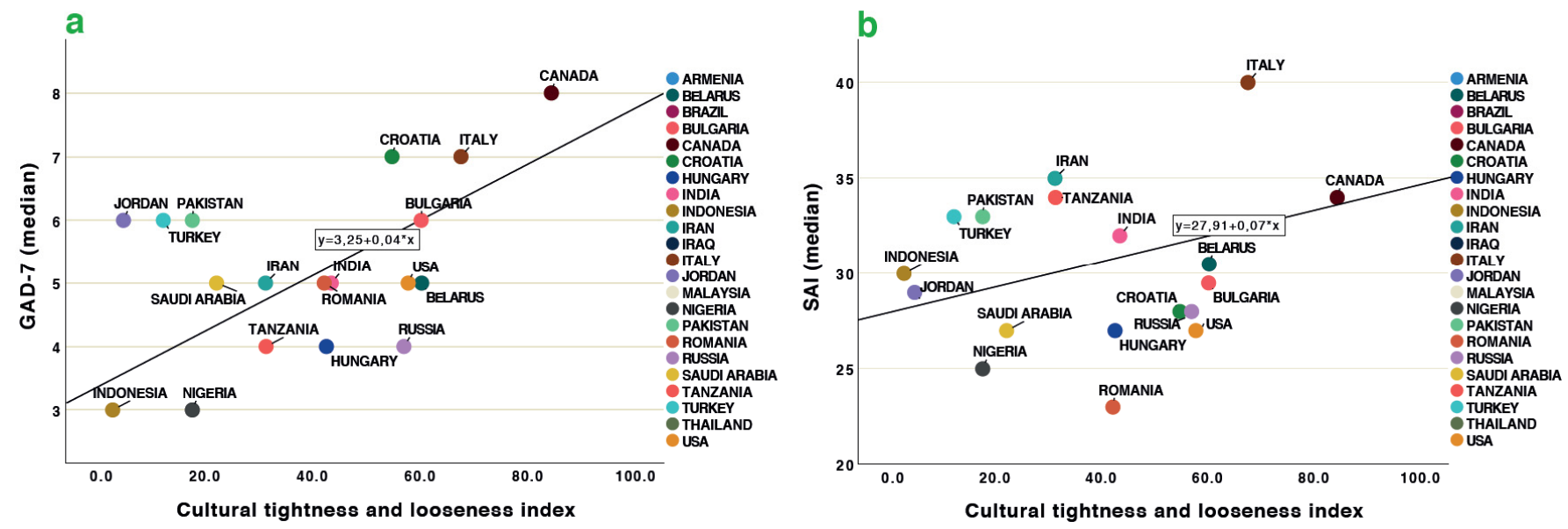

Figure 7. Association between CTL and GAD-7 (a), SAI (b) across 23 countries (Note that in the case of the Gelfand's index, the tightness increases along the $x$ axis, in Uz's study, the direction goes to the opposite-from tight to loose countries).

\subsection{Anxiety Scales, Age and Cohabitation/Loneliness}

As another factor possibly influencing the level of anxiety during pandemic, we used the factor of cohabitation/loneliness (live alone or live with other). Significant differences of cohabitation/loneliness were observed in the GAD-7 scale; people who lived with someone reported the highest levels of anxiety (Table 3, Figure 8a,b). The overwhelming majority of respondents $(90.8 \%)$ from our sample lived with someone, whether family members or friends (colleagues) (Table 4). In some countries we discovered a contrary tendency; that is the lonely people were more anxious. This was true for Belarus, Bulgaria, Malaysia and Pakistan, but these differences were not strong (Figure 8a).

Table 4. Differences in anxiety scales depending on cohabitation/loneliness across total sample.

\begin{tabular}{|c|c|c|c|c|c|c|c|c|c|}
\hline \multirow{2}{*}{ Scales } & \multirow{2}{*}{$\begin{array}{l}\text { Cohabitation/ } \\
\text { Loneliness }\end{array}$} & \multirow{2}{*}{$\mathbf{N}$} & \multirow{2}{*}{ Mean } & \multirow{2}{*}{$\mathbf{t}$} & \multirow{2}{*}{ df } & \multirow{2}{*}{$\mathbf{P}$} & \multicolumn{2}{|c|}{$95 \%$ CI } & \multirow{2}{*}{$\begin{array}{c}\text { Effect } \\
\text { Size }\end{array}$} \\
\hline & & & & & & & Lower & Upper & \\
\hline GAD-7 & $\begin{array}{l}\text { live with others } \\
\text { live alone }\end{array}$ & $\begin{array}{c}13,889 \\
1408\end{array}$ & $\begin{array}{l}6.08 \\
5.61\end{array}$ & 3.328 & 15295 & $<0.001$ & 0.193 & 0.745 & 0.093 \\
\hline SAI & $\begin{array}{l}\text { live with others } \\
\text { live alone }\end{array}$ & $\begin{array}{c}13,830 \\
1397\end{array}$ & $\begin{array}{l}30.88 \\
30.46\end{array}$ & 1.376 & 15,225 & NS & -0.175 & 1.001 & 0.039 \\
\hline
\end{tabular}

$\mathrm{N}$-number of cases, $\mathrm{t}$ - test statistics, $\mathrm{df}$ - degrees of freedom, $\mathrm{p}$-statistical significance, NS—not significant, $\mathrm{CI}$-Confidence Interval of the Difference. 


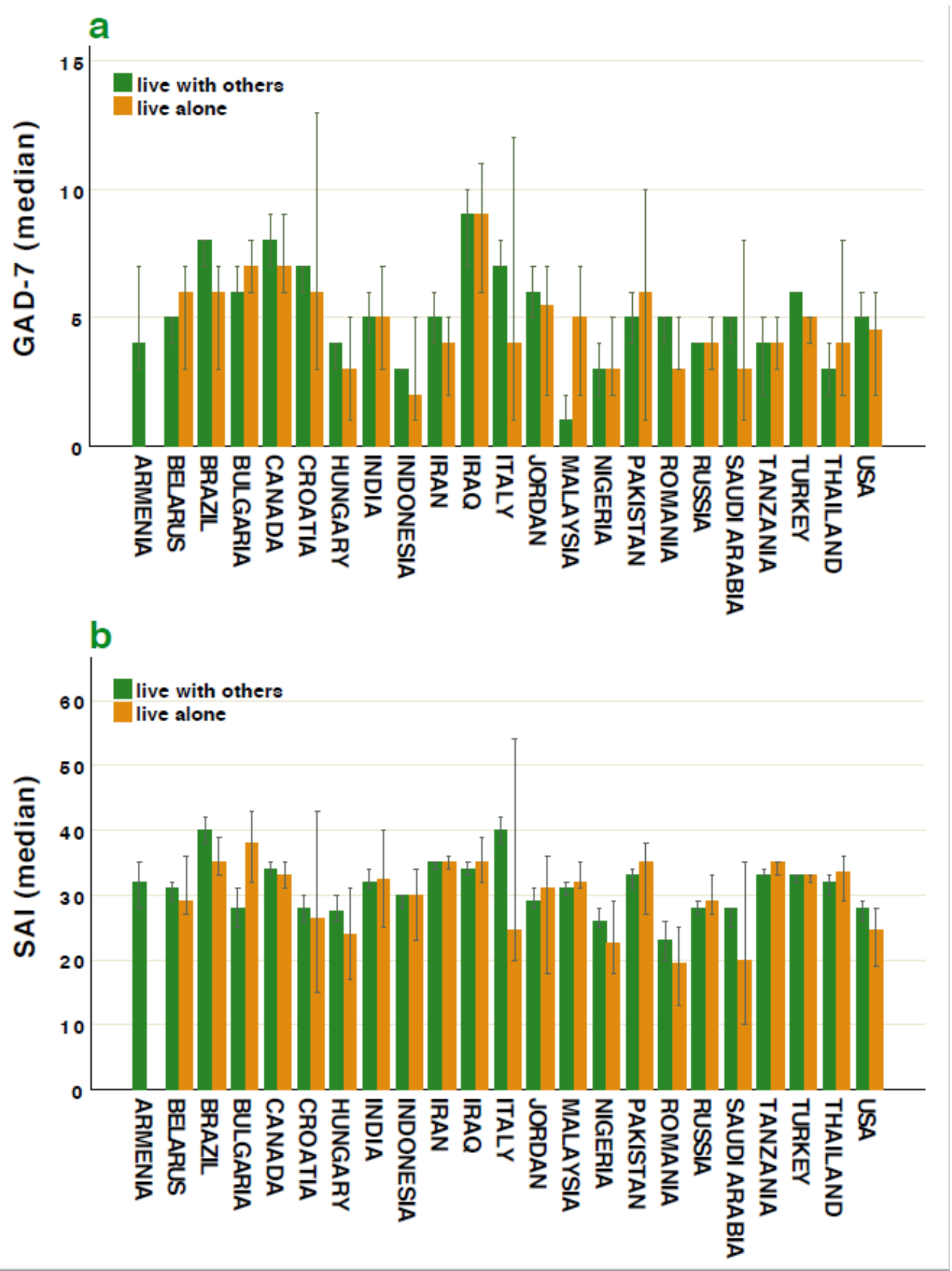

Figure 8. Differences in cohabitation/loneliness depending on GAD-7 (a) and SAI (b) across 23 countries.

A GLM ANCOVA two-way analysis was conducted with GAD-7 and SAI as dependent variables, sex, country and cohabitation/loneliness as independent predictors and age as a covariate for the whole sample (Table 5). It was found that age was significantly associated with anxiety in each combination, but the predictor "cohabitation/loneliness" depended on country of respondent in the case of the SAI scale exclusively (Table 5). 
Table 5. GLM ANCOVA analyses with GAD-7 and SAI as dependent variables, and sex, country and cohabitation/loneliness as independent predictors, with age as a covariate for the whole sample.

\begin{tabular}{|c|c|c|c|c|c|}
\hline Predictors & Dependent Variable & df & $\mathbf{F}$ & $p$ & $\eta^{2}$ \\
\hline \multirow{2}{*}{ Sex } & GAD-7 & 1 & 34.961 & $<0.001$ & 0.002 \\
\hline & SAI & 1 & 14.199 & $<0.001$ & 0.001 \\
\hline \multirow{2}{*}{ cohabitation/loneliness } & GAD-7 & 1 & 2.808 & 0.094 & 0.000 \\
\hline & SAI & 1 & 0.199 & 0.656 & 0.000 \\
\hline \multirow{2}{*}{ sex $\times$ cohabitation/loneliness } & GAD-7 & 1 & 0.109 & 0.742 & 0.000 \\
\hline & SAI & 1 & 0.946 & 0.331 & 0.000 \\
\hline \multirow{2}{*}{ Country } & GAD-7 & 22 & 7.770 & $<0.001$ & 0.011 \\
\hline & SAI & 22 & 9.566 & $<0.001$ & 0.014 \\
\hline \multirow{2}{*}{ Age } & GAD-7 & 1 & 26.639 & $<0.001$ & 0.002 \\
\hline & SAI & 1 & 21.149 & $<0.001$ & 0.001 \\
\hline \multirow{2}{*}{ country $\times$ age } & GAD-7 & 22 & 4.921 & $<0.001$ & 0.007 \\
\hline & SAI & 22 & 6.245 & $<0.001$ & 0.009 \\
\hline \multirow{2}{*}{$\begin{array}{l}\text { cohabitation/loneliness } \times \\
\text { country }\end{array}$} & GAD-7 & 21 & 1.192 & 0.246 & 0.002 \\
\hline & SAI & 21 & 1.835 & 0.011 & 0.003 \\
\hline \multirow{2}{*}{ sex $\times$ country } & GAD-7 & 22 & 1.357 & 0.122 & 0.002 \\
\hline & SAI & 22 & 3.875 & $<0.001$ & 0.006 \\
\hline \multirow{2}{*}{ cohabitation/loneliness $\times$ age } & GAD-7 & 1 & 3.562 & 0.059 & 0.000 \\
\hline & SAI & 1 & 0.022 & 0.883 & 0.000 \\
\hline \multirow{2}{*}{ sex $\times$ age } & GAD-7 & 1 & 14.066 & $<0.001$ & 0.001 \\
\hline & SAI & 1 & 0.997 & 0.318 & 0.000 \\
\hline
\end{tabular}

$\mathrm{R}^{2}(\mathrm{GAD}-7)=0.127 ; \mathrm{R}^{2}(\mathrm{SAI})=0.131 . \mathrm{R}^{2}-\mathrm{R}$ Squared. $\mathrm{df}$-degrees of freedom. $\mathrm{F}-\mathrm{F}$ test statistics. $p$-statistical significance. $\eta^{2}$-Partial Eta Squared effect size.

Across sexes, as the age of the respondents increased, the level of anxiety on both scales decreased (Figure 9a,b). There were no significant differences in the level of anxiety, decreasing with age in groups of people living alone or with someone (Figure 10a,b).

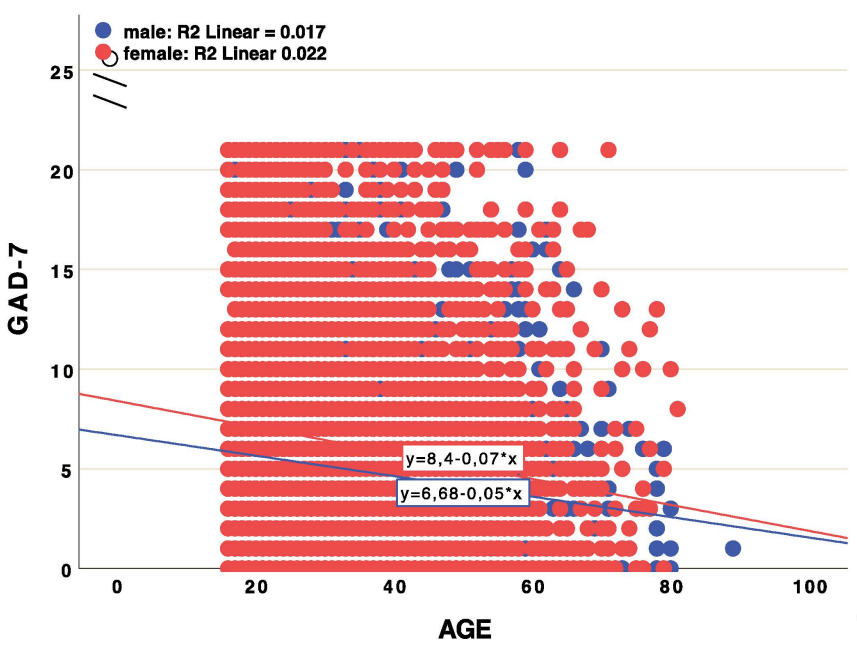

(a)

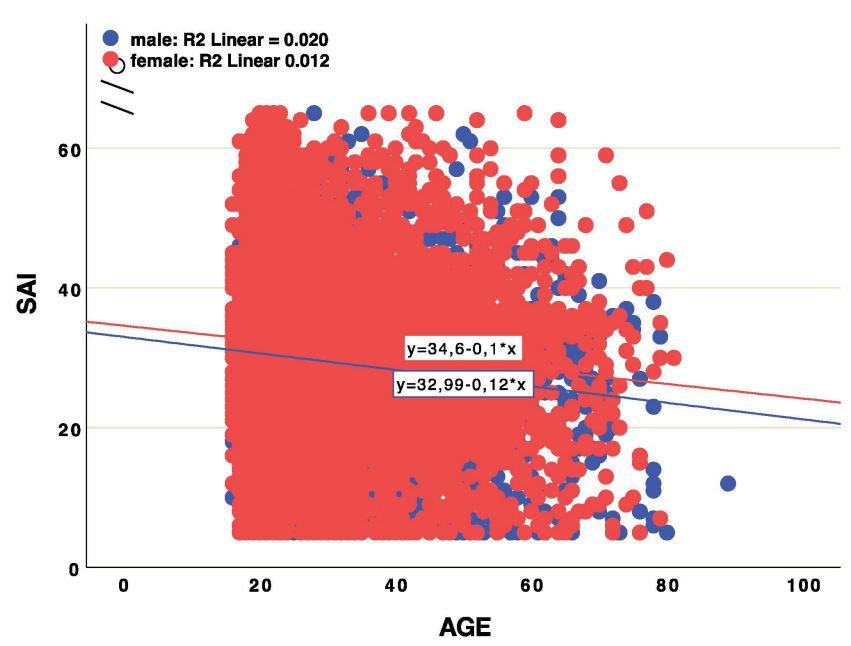

(b)

Figure 9. Association between age and GAD-7 (a), SAI (b) across total sample. 


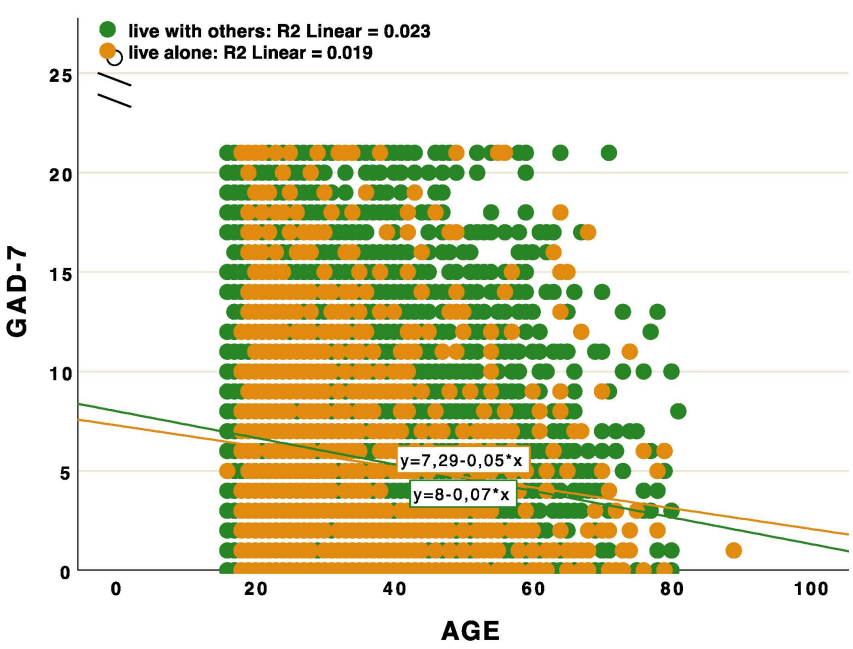

(a)

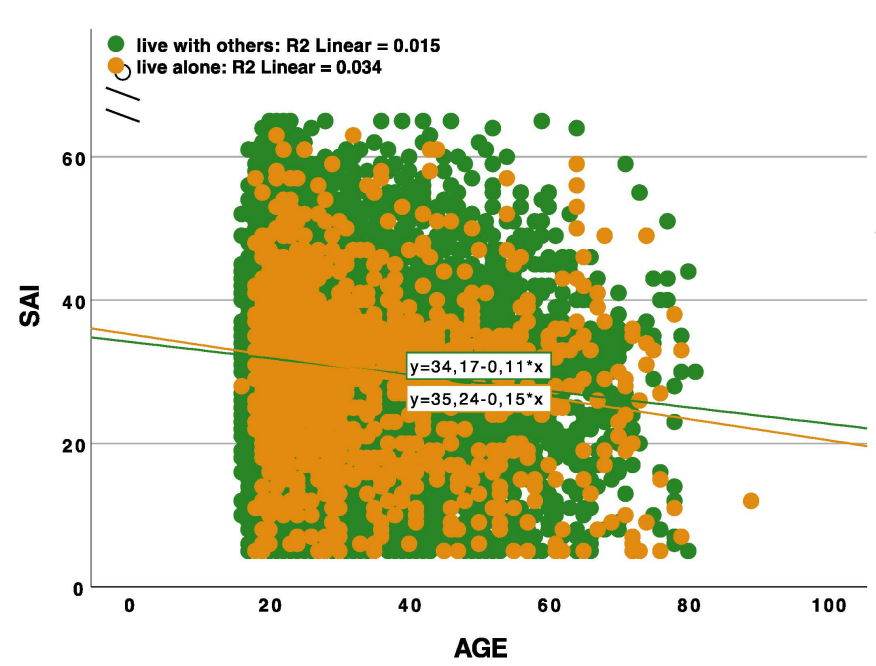

(b)

Figure 10. Association between GAD-7 (a), SAI (b) and age depending on cohabitation/loneliness across total sample.

\section{Discussion}

Based on cross-sectional data from 15,375 participants from 23 countries collected during the early phase of the COVID-19 pandemic, the data reflect that women reported higher levels of anxiety compared to men. This result supports prior research collected before the COVID-19 pandemic [19,23-25,52,65-69]. Importantly, however, when examining between-country differences, we did not find significant sex differences in the level of anxiety between men and women in Armenia, Hungary, Iran, Iraq, Saudi Arabia, Thailand and the USA. The COVID-19 outbreak in China did not result in sex differences in stress levels either [26,27]. However, this result may be culturally related. Recent studies of existing data indicate that GAD-7 rates vary by ethnic/cultural group [70].

Previous studies suggest cross-cultural differences in the prevalence of anxiety disorders [71,72], but the extent of these differences remains unclear. While symptoms of anxiety have been found more common in Latin America, high income regions and regions with a history of recent conflict [66], symptoms of anxiety tend to be less common in Asian populations compared to other populations $[66,71,72]$. Results from the present study showed the highest GAD-7 scores in Brazil, Iraq, Canada, the USA and Italy. Overall, our samples demonstrated that GAD-7 scores were higher during COVID-19 in comparison with scores before the pandemic (for which the similar data was available) (see Table 6). In Saudi Arabia the GAD-7 scores were close to the values reported by Al-Rabiaah and colleagues during the MERS-CoV outbreak in 2014 [52].

Table 6. The data of studies of GAD-7 before pandemic COVID-19.

\begin{tabular}{|c|c|c|c|c|c|c|}
\hline Countries & Sample: N (age) & GAD-7 * & GAD-7 Men & GAD-7 Women & Present Study & Source \\
\hline Bulgaria & $529(21.00)$ & 3.0 (median) & & & 6.0 (median) & [53] \\
\hline Brazil & $4001(18-60)$ & $2.2 \%$ severe level & - & - & $\begin{array}{c}17 \% \text { severe } \\
\text { level }\end{array}$ & [54] \\
\hline Canada & $610(21.35)$ & 5.82 (mean) & & & 8.23 & [70] \\
\hline Malaysia & $895(30.9 \pm 10.4)$ & $\begin{array}{l}7.8 \% \text { moderate and } \\
\text { severe levels }\end{array}$ & - & - & $\begin{array}{c}10 \% \text { moderate } \\
\text { and severe } \\
\text { levels }\end{array}$ & [55] \\
\hline Pakistan & $285(16-80)$ & 5.18 (mean) & - & - & 6.05 & {$[65]$} \\
\hline Russia & $132(18-46)$ & 3.35 (mean) & 3.51 & 3.19 & $4.76(3.80 ; 5.71)$ & [56] \\
\hline
\end{tabular}


Table 6. Cont

\begin{tabular}{|c|c|c|c|c|c|c|}
\hline Countries & Sample: N (age) & GAD-7 * & GAD-7 Men & GAD-7 Women & Present Study & Source \\
\hline Thailand & $800(18-24)$ & $\begin{array}{l}3.78 \text { (mean) } \\
7.8 \% \text { moderate and } \\
\text { severe levels }\end{array}$ & 3.65 & 3.91 & $\begin{array}{c}3.77(3.33 ; 4: 20) \\
11 \% \text { moderate } \\
\text { and severe } \\
\text { levels }\end{array}$ & [57] \\
\hline Turkey & $134(34.67 \pm 12.55)$ & 6.11 (mean) & - & - & 6.59 & [58] \\
\hline Saudi Arabia & $\begin{array}{c}200(21.6) \\
\text { medical students } \\
\text { during MERS-CoV } \\
2014 \\
192(20.50 \pm 1.96)\end{array}$ & $\begin{array}{c}5.09 \text { (mean) } \\
\text { 0\% severe level } \\
\text { - }\end{array}$ & $\begin{array}{l}4.56 \\
5.26\end{array}$ & $\begin{array}{c}5.61 \\
-\end{array}$ & $5.48(5.40 ; 5.55)$ & [52] \\
\hline $\begin{array}{c}\text { USA } \\
2009-2010 \\
2015 \\
2018-2019\end{array}$ & $\begin{array}{c}2740(47.4 \pm 15.5) \\
447(23.43) \\
1897(19.60 \pm 1.62) \\
426(20.19 \pm 1.82) \\
1805(20.44 \pm 1.47)\end{array}$ & $\begin{array}{c}4.68 \% \text { severe level } \\
5.06 \text { (mean) } \\
5.71 \text { (mean) } \\
6.28 \text { (mean) } \\
7.45 \text { (mean) }\end{array}$ & $\begin{array}{c}- \\
- \\
4.84 \\
5.99 \\
6.09\end{array}$ & $\begin{array}{c}- \\
- \\
6.57 \\
8.34 \\
8.81\end{array}$ & $\begin{array}{l}11 \% \text { severe } \\
\text { level } \\
6.19 \text { (mean) }\end{array}$ & $\begin{array}{l}{[50]} \\
{[70]} \\
{[67]}\end{array}$ \\
\hline
\end{tabular}

* we provide data (means, medians, percentages) that can be used to compare with our data.

Data from our study showed a positive association between age and reported symptoms of anxiety, which complements prior research $[3,26,66,73,74]$. At the same time, some data showed inverted U-shaped associations between age and well-being [23,69], or no association between age and stress [27]. In a study conducted earlier before the pandemic in Pakistan, age did not influence self-reported symptoms of the GAD-7 [65].

Approximately $91 \%$ of the participants in our study reported living with someone, whether family members or friends. Significant differences of cohabitation/loneliness were observed for the GAD-7 scale; particularly, people who lived with someone reported higher levels of anxiety. However, when we compared countries, we found that some countries showed the opposite association, i.e., people living alone were more anxious, for example in Belarus, Bulgaria, Malaysia, and Pakistan. Research has demonstrated that living alone may be linked to higher indices of depression and anxiety [28,75]. The same is true in the case of overcrowding $[32,33,73]$. Our total results are in line with the study of Kowal and colleagues (2020), who reported that people living alone were not stressed much [3]. On the other hand, the same studies suggested that married (or cohabiting) individuals experience lower levels of stress than single individuals $[3,76]$. The Chinese data reported no differences related to marital status on perceived stress during COVID-19 [27,77]. Such differences warrant further investigations.

Cultural considerations. Perhaps not surprisingly, our results showed that reported symptoms of anxiety differed across countries. Participants from countries with the highest ratings of anxiety (Canada and Italy) were also highest on individualism, whereas the least anxious countries were those with lowest levels of individualism (Thailand, Indonesia, Malaysia, Nigeria). High GAD-7 ratings on anxiety were found for nations with low power distance (Canada, Italy). Interestingly, participants in this study reported experiencing the pandemic as hypothesized by Triandis and colleagues (1990): in the individualistic cultures, people find it harder to give up their personal preferences for group needs, while collectivist countries focus on group harmony, and the emotional cost of a period of isolation is higher in individualistic cultures [38]. As expected, stress levels were higher for individualistic versus collectivist cultures in our study.

However, contrary to our results, prior research by Kowal and colleagues (2020) found the individualism-collectivism continuum not to be associated with perceived stress [3]. Mækel and colleagues (2020) proposed another way to interpret these associations by the locus of control theory (people with a high locus or a sense of control tend to behave in a way that promotes health) $[4,78]$. Participants in Brazil, Colombia and the USA reported higher levels of anxiety, whereas people from Israel, Germany and Norway 
had comparatively lower levels of anxiety [4]. More individualistic countries, such as Australia and Canada, tend to attribute more negative connotations to the external locus of control than more collectivistic ones [79]. As presented by Mækel et al. (2020), more individualistic countries such as Norway, Germany and the USA had relatively lower scores for the sense of control over the outbreak than the more collectivist Colombia and Brazil [4]. The tendency in associations between the level of anxiety and the individualismcollectivism dimension remains to be tested more precisely in the future studies. One of the possible directions is gene-environmental research. For example, Chiao and Blizinsky (2010) suggested that certain cultural values, such as collectivism, may protect genetically susceptible populations (e.g., East Asian populations) from the increasing prevalence of anxiety disorders [80]; a promising area for future research.

Similar results were found when examining associations with tightness and looseness as defined by Gelfand and colleagues [39]. Tight societies, such as Australia, Brazil, the Netherlands and New Zealand, restrict freedom, while loose societies such as Pakistan, Malaysia, Singapore and South Korea, allow for greater freedom [39]. Specifically, our participants from loose nations (e.g., Canada and Italy) reported higher symptoms of anxiety compared to those from tight nations (e.g., Indonesia, Jordan and Nigeria). According to Gelfand and colleagues (2014), both very permissive and very constrained nations exhibit lower happiness, higher suicide rates, lower life expectancy and greater mortality rates from cardiovascular disease and diabetes [39]. The authors suggest that these disadvantages (extremes of freedom or restrictions) may be a consequence of the inability to control oneself and one's environment [39].

Our data revealed a significant positive association between the level of anxiety during the COVID-19 first wave and countries' scores on the Infectious Disease Vulnerability Index. Countries most vulnerable in terms of infectious diseases (e.g., Nigeria, Tanzania, Pakistan) reported lower levels of anxiety compared to countries less experienced with severe infections (USA, Italy, Canada).

\section{Limitations}

The results of this study should be interpreted within the context of certain limitations. Limitations of the current study include the disproportionate representation of women to men. Relatedly, it is important to acknowledge that participants were asked their sex and not their gender identity, which limits the generalizability of the study's findings to individuals who may identify with a specific gender. Additionally, it is important to acknowledge that while the overall sample included over 15,000 participants, the representation in some countries (i.e., Armenia, Iraq) was quite low, which limits our ability to examine within-country differences. Another consideration is that participation in this study was limited to those with a stable internet connection (to complete the questionnaire), which precluded participation from those without this access.

We did not measure countries' policies relating to COVID-19 and mortality rates, which may also be an important predictor of anxiety increase. Future studies in this direction should be highly productive and may further extend our knowledge about the nature of human anxiety and it's influence of individual and public wellbeing.

\section{Conclusions}

Our study revealed cross-cultural differences in the level of anxiety during the first wave of the COVID-19 pandemic (from May to August 2020). Globally, levels of anxiety were higher in women compared to men. We suggest that cultural dimensions such as individualism/collectivism, power distance, and looseness/tightness may function as protective adaptive mechanisms against the development of anxiety symptoms in the continued COVID-19 pandemic. One possible explanation is that respondents from countries with higher power distance, tightness and collectivism, were less anxious and stressed because they trusted officials, and felt more that they were being protected by 
governmental services. Another possible explanation is that under such conditions, people do not feel able to influence the situation on their own.

This article presents the first results from our cross-cultural COVID-19 project. In the future we are planning to add more predictors into the analysis, including such factors as the degree of trust for the authorities, personal epidemiological experience, personal fear of COVID-19 and mortality rates for each country.

Author Contributions: Conceptualization, M.L.B., V.N.B.; Methodology, M.L.B., V.N.B., A.K.R.; Data analysis, M.L.B., V.N.B.; Data collections, all authors; Resources, all authors; Data curation, V.N.B.; Writing-original draft preparation M.L.B., V.N.B., A.K.R., L.H.; Visualization, M.L.B., V.N.B.; Project administration, M.L.B., V.N.B. All authors have read and agreed to the published version of the manuscript.

Funding: In Russia (V.N.B., M.L.B., J.F.), this article was prepared in the framework of a research grant funded by the Ministry of Science and Higher Education of the Russian Federation (grant ID: 075-15-2020-910). The authors extend their appreciation to the Deanship of Scientific Research at King Saud University for funding this work through Support to Ahmad M. Alghraibeh (Saudi Arabia). Data collection in Hungary was supported by the Hungarian Scientific Research Fund (OTKA) awarded to the twenty-seventh author (K125437).

Institutional Review Board Statement: The study was conducted according to the guidelines of the Declaration of Helsinki, and approved by the Ethics Committee of the Institute of Ethnology and Anthropology of the Russian Academy of Sciences (protocol No 01, dated 9 April 2020).

Informed Consent Statement: Informed consent was obtained from all subjects involved in the study.

Data Availability Statement: Data produced and processed in this study are included in the published article. The datasets can be acquired from the corresponding author upon appropriate purposes.

Conflicts of Interest: The authors declare no conflict of interest.

\section{References}

1. World Health Organization. WHO Director-General's Opening Remarks at the Media Briefing on COVID-19-11 March 2020. Available online: https: / www.who.int/director-general/speeches/detail/who-director-general-s-opening-remarks-at-themedia-briefing-on-covid-19---11-march-2020 (accessed on 12 February 2021).

2. Brooks, S.K.; Webster, R.K.; Smith, L.E.; Woodland, L.; Wessely, S.; Greenberg, N.; Rubin, G.J. The psychological impact of quarantine and how to reduce it: Rapid review of the evidence. Lancet 2020, 395, 912-920. [CrossRef]

3. Kowal, M.; Coll-Martín, T.; Ikizer, G.; Rasmussen, J.; Eichel, K.; Studzińska, A.; Ahmed, O. Who is the most stressed during the covid-19 pandemic? Data from 26 countries and areas. Appl. Psychol. Health Well-Being 2020, 12, 946-966. [CrossRef]

4. Mækelæ, M.J.; Reggev, N.; Dutra, N.; Tamayo, R.M.; Silva-Sobrinho, R.A.; Klevjer, K.; Pfuhl, G. Perceived efficacy of COVID-19 restrictions, reactions and their impact on mental health during the early phase of the outbreak in six countries. R. Soc. Open Sci. 2020, 7200644. [CrossRef]

5. Ornell, F.; Schuch, J.B.; Sordi, A.O.; Kessler, F.H.P. Pandemic fear and COVID-19: Mental health burden and strategies. Braz. J. Psychiatry 2020, 42, 232-235. [CrossRef]

6. van Bavel, J.J.; Baicker, K.; Boggio, P.S.; Capraro, V.; Cichocka, A.; Cikara, M.; Ellemers, N. Using social and behavioural science to support COVID-19 pandemic response. Nat. Hum. Behav. 2020, 4, 460-471. [CrossRef]

7. Fedenok, J.N.; Burkova, V.N. Social distancing as altruism in the context of the coronavirus pandemic: A cross-cultural study. Sib. Hist. Res. 2020, 2, 6-40. [CrossRef]

8. Cao, W.; Fang, Z.; Hou, G.; Han, M.; Xu, X.; Dong, J.; Zheng, J. The psychological impact of the COVID-19 epidemic on college students in China. Psychiatry Res. 2020, 112934. [CrossRef] [PubMed]

9. Chen, Q.; Liang, M.; Li, Y.; Guo, J.; Fei, D.; Wang, L.; He, L.; Sheng, C.; Cai, Y.; Li, X.; et al. Mental health care for medical staff in China during the COVID-19 outbreak. Lancet Psychiatry 2020, 7, e15-e16. [CrossRef]

10. Li, S.W.; Wang, Y.; Yang, Y.Y.; Lei, X.M.; Yang, Y.F. Analysis of influencing factors of anxiety and emotional disorders in children and adolescents during home isolation during the epidemic of novel coronavirus pneumonia. Chin. J. Child Health 2020, 28, 1-9.

11. Yang, Y.; Li, W.; Zhang, Q.; Zhang, L.; Cheung, T.; Xiang, Y.T. Mental health services for older adults in China during the COVID-19 outbreak. Lancet Psychiatry 2020, 7, e11. [CrossRef]

12. Bults, M.; Beaujean, D.J.M.A.; de Zwart, O.; Kok, G.; van Empelen, P.; van Steenbergen, J.E.; Richardus, J.H.; Voeten, H.A.C.M. Perceived risk, anxiety, and behavioural responses of the general public during the early phase of the Influenza A (H1N1) pandemic in the Netherlands: Results of three consecutive online surveys. BMC Public Health 2020, 11, 2. [CrossRef] [PubMed] 
13. Jalloh, M.F.; Li, W.; Bunnell, R.E.; Ethier, K.A.; O’Leary, A.; Hageman, K.M.; Sengeh, P.; Jalloh, M.B.; Morgan, O.; Hersey, S.; et al. Impact of Ebola experiences and risk perceptions on mental health in Sierra Leone, July 2015. BMJ Glob. Health 2018, 3 , e000471. [CrossRef] [PubMed]

14. Jones, J.H.; Salathe, M. Early assessment of anxiety and behavioral response to novel swine-origin influenza A (H1N1). PLoS ONE 2009, 4, e8032. [CrossRef] [PubMed]

15. Main, A.; Zhou, Q.; Ma, Y.; Luecken, L.J.; Liu, X. Relations of SARS-related stressors and coping to Chinese college students' psychological adjustment during the 2003 Beijing SARS epidemic. J. Couns. Psychol. 2011, 58, 410-423. [CrossRef]

16. Semenova, O.; Apalkova, J.; Butovskaya, M. Sex differences in spatial activity and anxiety levels in the COVID-19 pandemic from evolutionary perspective. Sustainability 2021, 13, 1110. [CrossRef]

17. Uehara, M.; Fujii, M.; Kobayashi, K. A model of stress change under the first COVID-19 pandemic among the general public in Japanese major cities and rural areas. Sustainability 2021, 13, 1207. [CrossRef]

18. Karwowski, M.; Kowal, M.; Groyecka, A.; Białek, M.; Lebuda, I.; Sorokowska, A.; Sorokowski, P. When in danger, turn right: Does Covid-19 threat promote social conservatism and right-wing presidential candidates? PsyArXiv 2020. Available online: https:/ / psyarxiv.com/pjfhs / (accessed on 8 February 2021). [CrossRef]

19. Cohen, S.; Janicki-Deverts, D.; Doyle, W.J.; Miller, G.E.; Frank, E.; Rabin, B.S.; Turner, R.B. Chronic stress, glucocorticoid receptor resistance, inflammation, and disease risk. Proc. Natl. Acad. Sci. USA 2012, 109, 5995-5999. [CrossRef]

20. Craske, M.; Rauch, S.; Ursano, R.; Prenoveau, J.; Pine, D.; Zinbarg, R. What is an anxiety disorder? Depress. Anxiety 2009, 26, 1066-1085. [CrossRef]

21. Toussaint, A.; Hüsing, P.; Gumz, A.; Wingenfeld, K.; Härter, M.; Schramm, E.; Löwe, B. Sensitivity to change and minimal clinically important difference of the 7-item Generalized Anxiety Disorder Questionnaire (GAD-7). J. Affect. Disord. 2020, 265, 395-401. [CrossRef]

22. Ahmed, M.A.-K.; Alansari, B.M. Gender differences in anxiety among undergraduates from ten Arab countries. Soc. Behav. Pers. 2004, 32, 649-655. [CrossRef]

23. Bergdahl, J.; Bergdahl, M. Perceived stress in adults: Prevalence and association of depression, anxiety and medication in a Swedish population. Stress Health 2002, 18, 235-241. [CrossRef]

24. Feingold, A. Gender differences in personality: A meta-analysis. Psychol. Bull. 1994, 116, 429-456. [CrossRef] [PubMed]

25. Burkova, V.N.; Butovskaya, M.L.; Dronova, D.A.; Apalkova, Y.I. Empathy, Anxiety, and Aggression among Moscow Students. Etnograficheskoe Obozr. 2019, 5, 169-188. (In Russian) [CrossRef]

26. Limcaoco, R.S.G.; Mateos, M.E.; Fernandez, M.J.; Roncero, C. Anxiety, worry and perceived stress in the world due to the COVID-19 pandemic. medRxiv 2020. [CrossRef]

27. Wang, C.; Pan, R.; Wan, X.; Tan, Y.; Xu, L.; Ho, C.S.; Ho, R.C. Immediate psychological responses and associated factors during the initial stage of the 2019 coronavirus disease (COVID-19) epidemic among the general population in China. Int. J. Environ. Res. Public Health 2020, 17, 1729. [CrossRef] [PubMed]

28. Jacob, L.; Haro, J.M.; Koyanagi, A. Relationship between living alone and common mental disorders in the 1993, 2000 and 2007 National Psychiatric Morbidity Surveys. PLoS ONE 2019, 14, e0215182. [CrossRef]

29. Kyprianides, A.; Easterbrook, M.J. Social factors boost well-being behind bars: The importance of individual and group ties for prisoner well-being. Appl. Psychol. Health Well-Being 2020, 12, 7-29. [CrossRef]

30. Vermeulen, L.P. Small-group behaviour in long-term isolation. S. Afr. J. Sociol. 1977, 15, 35-40. [CrossRef]

31. Rico-Uribe, L.A.; Caballero, F.F.; Martín-María, N.; Cabello, M.; Ayuso-Mateos, J.L.; Miret, M. Association of loneliness with all-cause mortality: A meta-analysis. PLoS ONE 2018, 13, e0190033. [CrossRef]

32. Epstein, Y.M. Crowding stress and human behavior. J. Soc. Issues 1981, 37, 126-144. [CrossRef]

33. Fuller, T.D.; Edwards, J.N.; Vorakitphokatorn, S.; Sermsri, S. Chronic stress and psychological well-being: Evidence from Thailand on household crowding. Soc. Sci. Med. 1996, 42, 265-280. [CrossRef]

34. Heppner, P.P. Expanding the conceptualization and measurement of applied problem solving and coping: From stages to dimensions to the almost forgotten cultural context. Am. Psychol. 2008, 63, 805-816. [CrossRef] [PubMed]

35. Wong, P.T.P.; Wong, L.C.J. Handbook of Multicultural Perspectives on Stress and Coping; Springer: New York, NY, USA, 2006.

36. Hofstede, G. Culture's Consequences: Comparing Values, Behaviors, Institutions and Organizations across Nations; Sage: Thousand Oaks, CA, USA, 2001.

37. Hofstede, G. Dimensionalizing cultures: The Hofstede model in context. Online Read. Psychol. Cult. (ORPC) 2011, 2, 3-26. [CrossRef]

38. Triandis, H.C.; McCusker, C.; Hui, C.H. Multimethod probes of individualism and collectivism. J. Personal. Soc. Psychol. 1990, 59, 1006-1020. [CrossRef]

39. Gelfand, M.J.; Raver, J.L.; Nishii, L.; Leslie, L.M.; Lun, J.; Lim, B.C.; Yamaguchi, S. Differences between tight and loose cultures: A 33-nation study. Science 2011, 332, 1100-1104. [CrossRef]

40. Brueck, H.; Business Insider. Singapore is Working "Round the Clock" to Find Coronavirus Cases. Lying about Where You've Been can Result in 6 Months of Jail or a Fine of up to $\$ 10,000$. Available online: https: / /www.businessinsider.com/singaporecoronavirus-quarantine-lying-to-investigators-jail-fine-2020-3?r=US\&IR=T (accessed on 5 March 2020).

41. Carpenter, S. Effects of cultural tightness and collectivism on self-concept and causal attributions. Cross-Cult. Res. 2000, 34, 38-56. [CrossRef] 
42. Cao, C.; Li, N.; Liu, L. Do national cultures matter in the containment of COVID-19? Int. J. Sociol. Soc. Policy 2020. [CrossRef]

43. de Kloet, E.R.; Joels, M.; Holsboer, F. Stress and the brain: From adaptation to disease. Nat. Rev. Neurosci. $2005,6,463-475$. [CrossRef]

44. Siervo, M.; Wells, J.C.; Cizza, G. Contribution of psychosocial stress to the obesity epidemic: An evolutionary approach. Horm. Metab. Res. 2009, 41, 261. [CrossRef]

45. Vinkers, C.H.; van Amelsvoort, T.; Bisson, J.I.; Branchi, I.; Cryan, J.F.; Domschke, K.; van der Wee, N.J. Stress resilience during the coronavirus pandemic. Eur. Neuropsychopharmacol. 2020, 35, 12-16. [CrossRef] [PubMed]

46. Reissman, D.B.; Watson, P.J.; Klomp, R.W.; Tanielian, T.L.; Prior, S.D. Pandemic influenza preparedness: Adaptive responses to an evolving challenge. J. Homel. Secur. Emerg. Manag. 2006, 3, 1-26. [CrossRef]

47. O'Connor, R.; Wetherall, K.; Cleare, S.; McClelland, H.; Melson, A.; Niedzwiedz, C.; Robb, K. Mental health and well-being during the COVID-19 pandemic: Longitudinal analyses of adults in the UK COVID-19 Mental Health \& Wellbeing study. Br. J. Psychiatry 2020, 1-8. [CrossRef]

48. Brislin, R.W. Back-translation for cross-cultural research. J. Cross-Cult. Psychol. 1970, 1, 185-216. [CrossRef]

49. Sousa, V.D.; Rojjanasrirat, W. Translation, adaptation and validation of instruments or scales for use in cross-cultural health care research: A clear and user-friendly guideline. J. Eval. Clin. Pract. 2011, 17, 268-274. [CrossRef]

50. Spitzer, R.L.; Kroenke, K.; Williams, J.B.W.; Lowe, B. A brief measure for assessing generalized anxiety disorder. Arch. Int. Med. 2006, 166, 1092-1097. [CrossRef] [PubMed]

51. Spielberger, C.D. Manual for the State-Trait Anxiety Inventory: STAI (Form Y); Consulting Psychologists Press: Palo Alto, CA, USA, 1983.

52. Al-Rabiaah, A.; Temsah, M.H.; Al-Eyadhy, A.A.; Hasan, G.M.; Al-Zamil, F.; Al-Subaie, S.; Somily, A.M. Middle East Respiratory Syndrome-Corona Virus (MERS-CoV) associated stress among medical students at a university teaching hospital in Saudi Arabia. J. Infect. Public Health 2020, 13, 687-691. [CrossRef]

53. Dzhambov, A.M.; Tilov, B.G.; Makakova, D.R.; Dimitrova, D.D. Psychometric properties and contribution to mental health of the Bulgarian version of the 4-factor Ruminative Thought Style Questionnaire. Folia Med. (Plovdiv) 2019, 61, 529-539. [CrossRef]

54. Silva, M.T.; Roa, M.C.; Martins, S.S.; da Silva, A.T.C.; Galvao, T.F. Generalized anxiety disorder and associated factors in adults in the Amazon, Brazil: A population-based study. J. Affect. Disord. 2018, 236, 180-186. [CrossRef] [PubMed]

55. Sidik, S.M.; Arroll, B.; Goodyear-Smith, F. Validation of the GAD-7 (Malay version) among women attending a primary care clinic in Malaysia. J. Prim. Health Care 2012, 4, 5-11. [CrossRef]

56. Esipenko, E.A.; Beloplotova, K.E.; Sharafieva, K.R.; Ismatullina, V.I. Anxiety (personal and spatial among students of different sex as factor of success in decision of spatial dillems. Subj. Pers. Psychol. Self-Regul. 2018, 77-82. (In Russian) [CrossRef]

57. Musumari, P.M.; Tangmunkongvorakul, A.; Srithanaviboonchai, K.; Techasrivichien, T.; Suguimoto, S.P.; Ono-Kihara, M.; Kihara, M. Grit is associated with lower level of depression and anxiety among university students in Chiang Mai, Thailand: A cross-sectional study. PLoS ONE 2018, 13, e0209121. [CrossRef]

58. Bozukluğu, Y.A.; Uyarlaması, T.T.; ve Güvenirliği, G. Validity and reliability study for the Turkish adaptation of the Generalized Anxiety Disorder-7 (GAD-7) scale. Arch. Neuropsychiatry 2013, 50, 53-58. [CrossRef]

59. Bahammam Maha, A. Validity and reliability of an Arabic version of the state-trait anxiety inventory in a Saudi dental setting. Saudi Med. J. 2016, 37, 668-674. [CrossRef]

60. Hanin, Y.L.; Spielberger, C.D. The development and validation of the Russian form of the state-trait anxiety inventory. In Series in Clinical E Community Psychology: Stress E Anxiety; HarperCollins: New York, NY, USA, 1980; pp. 15-26.

61. Sipos, K.; Sipos, M. The development and validation of the Hungarian form of the state-trait anxiety inventory. In Series in Clinical $\mathcal{E}$ Community Psychology: Stress \& Anxiety; HarperCollins: New York, NY, USA, 1980; pp. 27-39.

62. Moreno, E.; Muñoz-Navarro, R.; Medrano, L.A.; González-Blanch, C.; Ruiz-Rodríguez, P.; Limonero, J.T.; Moretti, L.S.; CanoVindel, A.; Moriana, J.A. Factorial invariance of a computerized version of the GAD-7 across various demographic groups and over time in primary care patients. J. Affect. Disord. 2019, 252, 114-121. [CrossRef]

63. Uz, I. The index of cultural tightness and looseness among 68 countries. J. Cross-Cult. Psychol. 2015, 46, 319-335. [CrossRef]

64. Moore, M.; Gelfeld, B.; Okunogbe, A.; Paul, C. Identifying Future Disease Hot Spots. Infectious Disease Vulnerability Index; RAND Corporation: Santa Monica, CA, USA, 2016; p. 81. [CrossRef]

65. Ahmad, S.; Hussain, S.; Shah, F.S.; Akhtar, F. Urdu translation and validation of GAD-7: A screening and rating tool for anxiety symptoms in primary health care. J. Pak. Med. Assoc. 2017, 67, 1536-1540.

66. Baxter, A.J.; Vos, T.; Scott, K.M.; Norman, R.E.; Flaxman, A.D.; Blore, J.; Whiteford, H.A. The regional distribution of anxiety disorders: Implications for the Global Burden of Disease Study, 2010. Int. J. Methods Psychiatr. Res. 2014, 23, 422-438. [CrossRef]

67. Byrd-Bredbenner, C.; Eck, K.; Quick, V. Psychometric properties of the generalized anxiety disorder-7 and generalized anxiety disorder-mini in United States university students. Front. Psychol. 2020, 11, 2512. [CrossRef] [PubMed]

68. Jaehn, P.; Bobrova, N.; Saburova, L.; Kudryavtsev, A.V.; Malyutina, S.; Cook, S. The relation of gender role attitudes with depression and generalised anxiety disorder in two Russian cities. J. Affect. Disord. 2020, 264, 348-357. [CrossRef] [PubMed]

69. Stone, A.A.; Schwartz, J.E.; Broderick, J.E.; Deaton, A. A snapshot of the age distribution of psychological well-being in the United States. Proc. Natl. Acad. Sci. USA 2010, 107, 9985-9990. [CrossRef] [PubMed]

70. Parkerson, H.A.; Thibodeau, M.A.; Brandt, C.P.; Zvolensky, M.J.; Asmundson, G.J. Cultural-based biases of the GAD-7. J. Anxiety Disord. 2015, 31, 38-42. [CrossRef] [PubMed] 
71. Kessler, R.C.; Ruscio, A.M.; Shear, K.; Wittchen, H.-U. Epidemiology of anxiety disorders. In Behavioral Neurobiology of Anxiety and its Treatment, Current Topics in Behavioral Neurosciences; Stein, M.B., Steckler, V.T., Eds.; Springer: Berlin/Heidelberg, Germany, 2010; pp. 21-35.

72. Baxter, A.J.; Scott, K.M.; Vos, T.; Whiteford, H.A. Global prevalence of anxiety disorders: A systematic review and metaregression. Psychol. Med. 2013, 43, 897-910. [CrossRef] [PubMed]

73. Archer, J.A.; Lim, Z.M.T.; Teh, H.C.; Chang, W.C.; Chen, S.H.A. The effect of age on the relationship between stress, well-being and health in a Singaporean sample. Ageing Int. 2015, 40, 413-425. [CrossRef]

74. Feizi, A.; Aliyari, R.; Roohafza, H. Association of perceived stress with stressful life events, lifestyle and sociodemographic factors: A large-scale community-based study using logistic quantile regression. Comput. Math. Methods Med. 2012, 151865. [CrossRef]

75. Cohen, S.; Wills, T.A. Stress, social support, and the buffering hypothesis. Psychol. Bull. 1985, 98, 310-357. [CrossRef]

76. Odriozola-Gonzalez, P.; Planchuelo-Gomez, A.; Irurtia-Muniz, M.J.; de Luis-Garcia, R. Psychological symptoms of the outbreak of the COVID-19 crisis and confinement in the population of Spain. PsyArXiv 2020. [CrossRef]

77. Tian, F.; Li, H.; Tian, S.; Yang, J.; Shao, J.; Tian, C. Psychological symptoms of ordinary Chinese citizens based on SCL-90 during the level I emergency response to COVID-19. Psychiatry Res. 2020, 288, 112992. [CrossRef]

78. Steptoe, A.; Wardle, J. Locus of control and health behaviour revisited: A multivariate analysis of young adults from 18 countries. Br. J. Psychol. 2001, 92, 659-672. [CrossRef]

79. Cheng, C.; Cheung, S.F.; Chio, J.H.; Chan, M.P. Cultural meaning of perceived control: A meta-analysis of locus of control and psychological symptoms across 18 cultural regions. Psychol. Bull. 2013, 139, 152-188. [CrossRef]

80. Chiao, J.Y.; Blizinsky, K.D. Culture-gene coevolution of individualism-collectivism and the serotonin transporter gene. Proc. R. Soc. B 2010, 277, 529-537. [CrossRef] [PubMed] 